\title{
New antimicrobial peptide kills drug-resistant pathogens without detectable resistance
}

\author{
Jong-Kook Lee ${ }^{1,3}$, Tudor Luchian ${ }^{2}$ and Yoonkyung Park ${ }^{1,3}$ \\ ${ }^{1}$ Research Center for Proteinaceous Materials, Chosun University, Gwangju, Korea \\ ${ }^{2}$ Department of Physics, Alexandru I. Cuza University, Iasi, Romania \\ ${ }^{3}$ Department of Biomedical Science, Chosun University, Gwangju, Korea \\ Correspondence to: Yoonkyung Park, email:y_k_park@chosun.ac.kr \\ Tudor Luchian, email: Iuchian@vaic.ro \\ Keywords: Staphylococcus aureus; clavaspirin peptide (CSP); toll-like receptor-2 (TLR-2); nuclear factor-kappa B (NF-KB); pro- \\ inflammatory cytokine \\ Received: November 03, 2017 Accepted: February 20, 2018 Epub: February 26, 2018 Published: March 20, 2018 \\ Copyright: Lee et al. This is an open-access article distributed under the terms of the Creative Commons Attribution License 3.0 \\ (CC BY 3.0), which permits unrestricted use, distribution, and reproduction in any medium, provided the original author and source \\ are credited.
}

\section{ABSTRACT}

Clavaspirin peptide (CSP) is derived from the pharyngeal tissues of the tunicate Styela clava. The 23-amino acid peptide is histidine-rich and amidated at the $\mathrm{N}$-terminus. CSP possesses low antimicrobial and high hemolytic activity at pH 7.4. Therefore, we designed 4 CSP analogs with substituted hydrophobic amino acids to reduce hydrophobic amino acid interactions. These modifications reduced the aggregation and cytotoxicity of the analogs at pH 7.4. The analogs also showed potent antimicrobial activity by accumulating on bacterial cell surfaces and inducing the lytic mechanism against gram-negative and gram-positive cells at pH 5.5 and 7.4. Moreover, exposure to the CSP-4 analog for up to 29 passages did not induce drug resistance in Staphylococcus aureus. Application of CSP-4 to inflamed skin of hairless mice infected with drug-resistant S. aureus (DRSA) significantly reduced skin infections without damaging dermal collagen or elastin. Topically applied CSP4 penetrated $25-40 \mu \mathrm{m}$ in the dermis within $30 \mathrm{~min}$, reducing the levels of Toll-like receptor-2, nuclear factor kappa B (NF-kB), and the pro-inflammatory cytokines tumor necrosis factor- $a$ (TNF- $\alpha$ ) and interleukin-1 $\beta$ (IL-1 $\beta$ ). These results suggest that CSP-4 could be a promising topical antimicrobial agent for skin diseases caused by DRSA such as S. aureus CCARM 0027.

\section{INTRODUCTION}

The common use of antibiotics against bacteria has led to the emergence of many antibiotic-resistant pathogen strains. As a result, infections caused by multidrug resistant bacteria have become a significant problem. It is estimated that in Europe alone there are 171,200 healthcare-associated infections with multidrug-resistant Staphylococcus aureus (MRSA) each year, affecting both adults and children [1, 2]. Thus, there is an urgent need to develop new antibiotic agents. One potentially effective strategy is to develop new agents derived from antimicrobial peptides (AMPs) [3], which are produced natively as part of the host defense response to microbial infections. Specifically, more than
20 AMPs have been identified in cases of drug-resistant S. aureus (DRSA), a leading cause of skin and soft tissue infections. Susceptibility to DRSA-associated infectious disease appears to be related to immunity mechanisms [4-8]. DRSA is associated with porcine reproductive and respiratory syndrome [4], the activation of nuclear factor kappa B (NF- $\mathrm{kB})$ [5]. It is also associated with the production of cytokines, including tumor necrosis factor alpha (TNF- $\alpha$ ) and interleukin (IL)-6, IL-1 $\alpha$, and IL-1 $\beta$ [6]; chemokines, including CXCL1, CXCL2, IL-8, and CXCR2 [7]; and AMPs, including defensins and cathelicidin [8].

Marine invertebrates lack acquired or memorytype immunity and rely solely on innate immunity mechanisms [9]. In a previous report, a gene involved 
in an innate immune mechanism, AMP from marine invertebrates, clavaspirin peptide (CSP), was cloned from a cDNA library prepared from the pharyngeal tissues of a tunicate, Styela clava. CSP has a histidine-rich, $\alpha$-helical structure composed of 23 amino acid residues. It exhibits antimicrobial activity against both gram-negative and gram-positive bacteria at low $\mathrm{pH}$, but its activity is diminished at $\mathrm{pH}$ 7.4. In addition, CSP induces hemolysis in both human and bovine red blood cells (RBCs) [10].

Understanding how the toxicity of these AMPs is controlled is very important, as toxicity is one of the major challenges in their general application for treating infection. A leucine, tryptophan, or phenylalanine zipper motif has been reported to play a key role in the toxic activity of AMPs, but does not affect its antimicrobial activity [11-13].

In the present study, we modified CSP by replacing two of the hydrophobic amino acids in its leucine-zipper motif with more hydrophilic residues. The resultant peptide, CSP-4, displayed low cytotoxicity, even at high concentrations, and reduced the spread of bacterial infection in a mouse model of dermal infection. Moreover, CSP-4 exhibited strong $\mathrm{pH}$-independent antimicrobial activity (including against DRSA) stemming from its ability to disrupt the cell membrane of microorganisms. CSP-4 repressed pro-inflammatory cytokines and inhibited DRSA-induced dermatitis in hairless mice. Additionally, CSP-4 did not induce resistance against tested bacteria when compared with commercial antibiotics such as daptomycin and linezolid. Therefore, CSP-4 may have therapeutic potential for dermatitis.

\section{RESULTS}

\section{Development of New AMPs}

Previous studies demonstrated that CSP has weak antimicrobial activity and high hemolytic activity towards mammalian RBCs at physiological $\mathrm{pH}(\mathrm{pH}$ 7.4) [10]. We therefore designed a set of CSP analogs to produce peptides exhibiting three features essential for therapeutic efficacy against dermatitis infection: 1) minimal aggregation at $\mathrm{pH}$ 5.5 and $7.4 ; 2$ ) strong antimicrobial activity at $\mathrm{pH} 5.5$ and 7.4; and 3) low or no cytotoxicity towards mammalian cells at pH 5.5 and 7.4. CSP has a helix-loop-helix [14] and a leucine-zipper motif (Figure 1A and Figure 1C) [15]. Isoleucine and leucine residues at positions 2, 5, 9, and 12 face each other to form a leucine-zipper motif and contribute to the high hydrophobicity of CSP, leading to its aggregation at $\mathrm{pH}$ 7.4. In this study, we prepared four CSP analogs (CSP-1, CSP-2, CSP-3, and CSP-4) by substituting combinations of two of the isoleucine and leucine residues with alanine or lysine to dissociate the leucine and/or isoleucine zipper motif (Figure 1B, Figure 1D and Supplementary Table 1). $\mathrm{C}_{18}$ reversed-phase highperformance liquid chromatography confirmed that the hydrophobicity of the synthetic CSP analogs was reduced. Moreover, the analogs exhibited lower minimum inhibitory concentrations (MICs) toward various microorganisms at pH 7.4, but less hemolytic activity and cytotoxicity than CSP against mammalian cells (Supplementary Table 1).

We visualized cell membrane damage induced by the CSP analogues and assessed their binding affinities for human (h)RBCs and HaCaT cells. Treatment with CSP-2 induced membrane shrinkage in hRBCs, whereas rhodamine-labeled CSP-3 bound to the cell membrane of $\mathrm{HaCaT}$ cells with high affinity. In contrast, CSP-4 displayed no detectable hemolytic or membrane-binding activity (Supplementary Figure 1). Of the four synthetic analogs, CSP-4 showed the lowest hydrophobicity and cytotoxicity (Table 1 and Supplementary Figure 1). Using a microdilution assay, we compared the antimicrobial activities of CSP-4, melittin, and four conventional antibiotics (erythromycin, ampicillin, gentamicin, and piperacidin) toward $S$. aureus and its drug-resistant strains. As shown in Table 1, the MIC of CSP-4 was lower against drug-resistant Escherichia coli, Pseudomonas aeruginosa, and $S$. aureus strains than other antibiotic drugs.

\section{Induction of resistance}

To determine the MIC of CSP-4 against $S$. aureus, we cultured a single colony of $S$. aureus ATCC 25923 and then passaged the cells up to 30 times to determine whether prolonged exposure to CSP-4 led to drug resistance. The conventional antibiotics linezolid and daptomycin were also tested as positive controls. The MIC for linezolid was increased by approximately $200 \times$ after 8 passages at $\mathrm{pH} 7.4$, whereas the MIC for daptomycin was increased by approximately $1000 \times$ after 8 passages at $\mathrm{pH}$ 7.4 , and over $8000 \times$ after 29 passages at pH 5.5 (Figure 2A, 2B). In contrast, the MIC for CSP-4 increased by only approximately $2 \times(16$ vs. $8 \mu \mathrm{M})$ after exposure for 29 passages. Thus, CSP-4 exhibited long-term antibacterial activity against $S$. aureus with minimal development of drug resistance.

\section{Anti-inflammatory effect}

We assessed the binding affinity of CSP-4 for LPS and LTA. LPS or LTA $(9 \mu \mathrm{g})$ was incubated with dansyl polymyxin $\mathrm{B}(2.5 \mu \mathrm{M})$ in $5 \mathrm{mM}$ HEPES buffer and the concentration of CSP-4 was increased in $0.4-\mu \mathrm{M}$ increments. Addition of CSP-4 led to a dose-dependent increase in fluorescence intensity, indicating successful binding of CSP4 to LPS or LTA (Figure 3A and Figure 3B). CSP-4 also inhibited the expression of the pro-inflammatory cytokines TNF- $\alpha$ and IL-1 $\beta$ in RAW 264.7 macrophages exposed to $S$. aureus CCARM 0027. As shown in Figure 3C, CSP-4 significantly decreased TNF- $\alpha$ and IL- $1 \beta$ levels compared to in cells exposed to $S$. aureus CCARM 0027 alone. The ability of $100 \mu \mathrm{g} / \mathrm{mL} \mathrm{CSP}-4$ to neutralize $1 \mu \mathrm{g} / \mathrm{mL}$ 
A

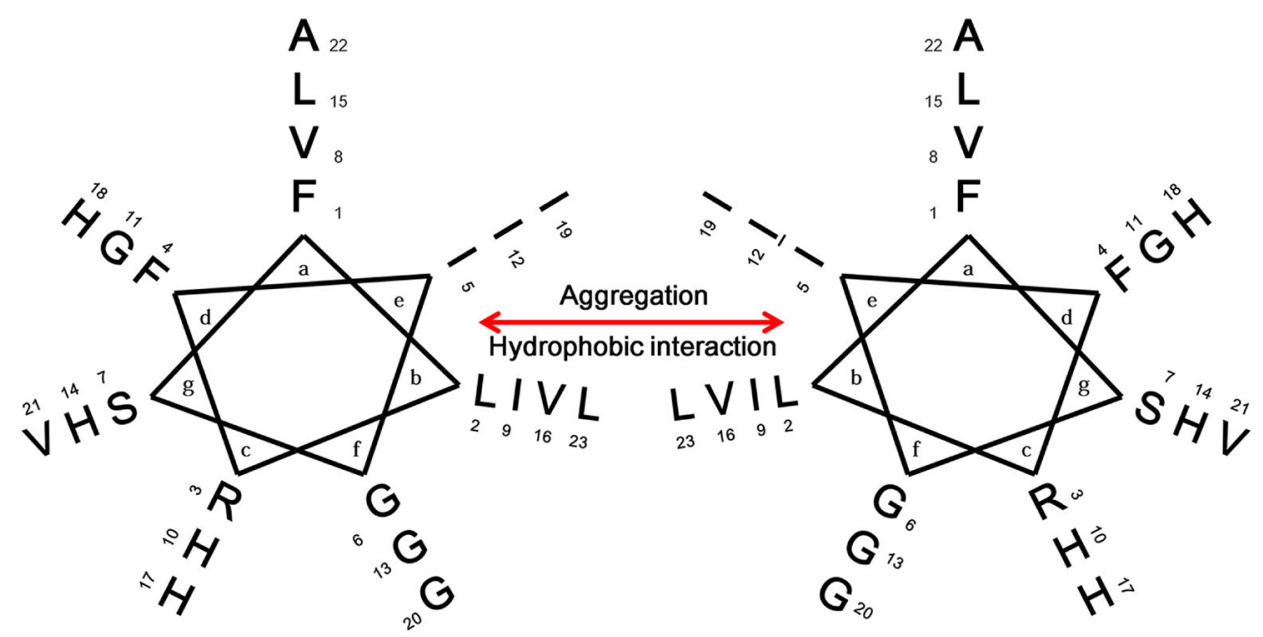

B

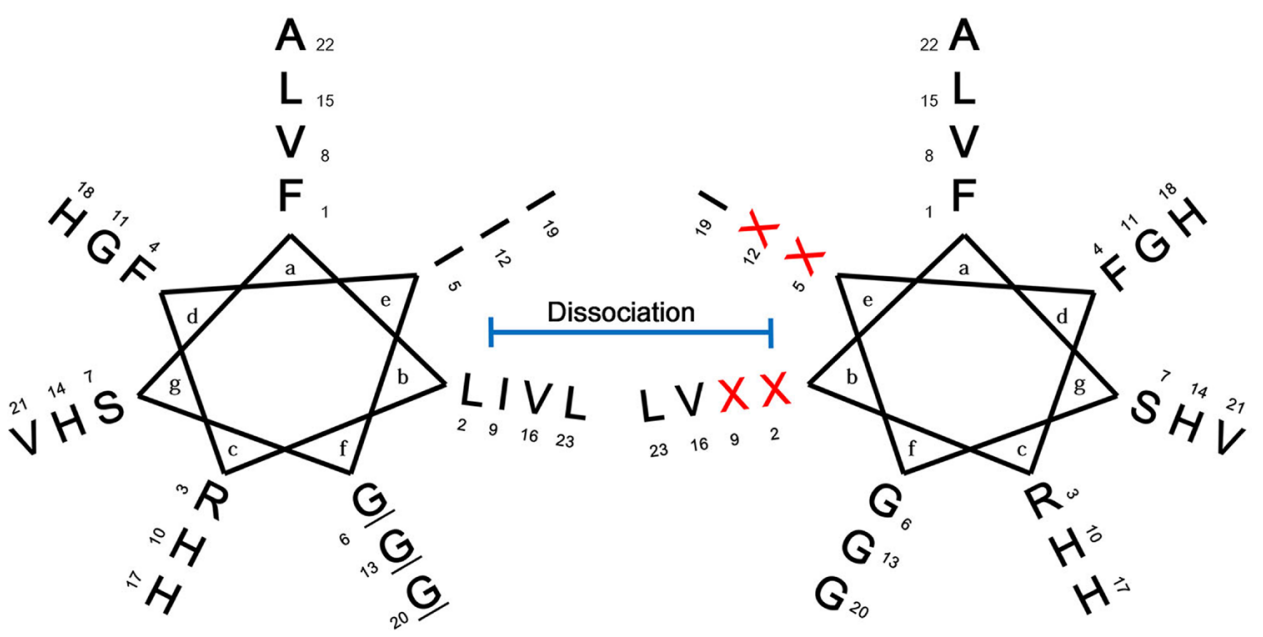

C

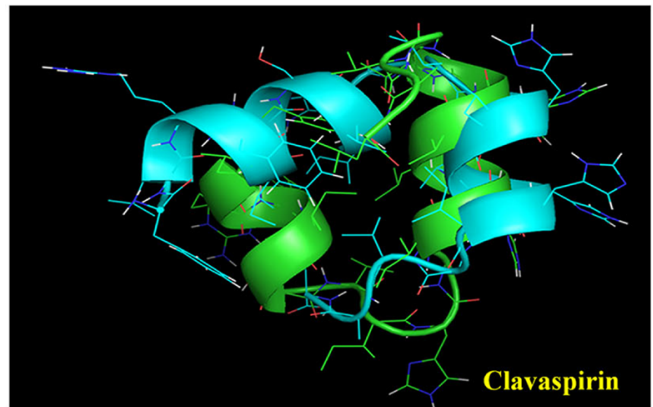

D

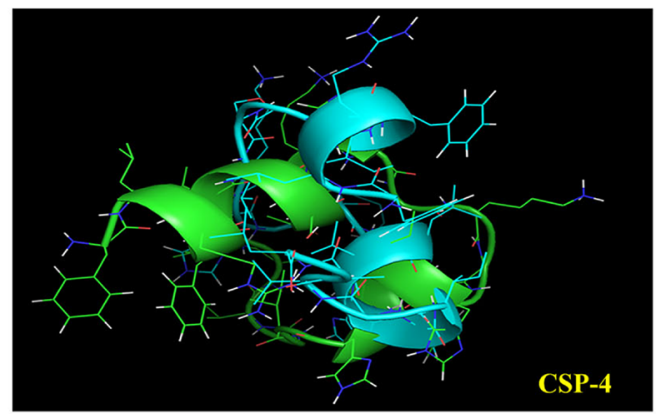

Figure 1: Helical wheel diagram structure of the clavaspirin peptide (CSP) and its analogs. (A) CSP possesses a $3_{10}$-helical structure (coiled-coil) and a leucine-zipper motif. The residue positions are labeled from a to g. Hydrophobic interactions between amino acid residues in positions e and b appear in the helical wheel diagram structure. (B) Isoleucine and leucine residues at positions 2, 5, 9, and 12 are located in the same face, allowing for the formation of a leucine-zipper. Analogue peptides were designed by substitution of the $\mathrm{X}$ position amino acid. We designed 4 peptide analogs by substituting the hydrophobic amino acids (CSP-1, I5A, and I12A; CSP-2, I5K, and I12K; CSP-3, L2K, and I9K; and CSP-4, I9K, and I12K) in the leucine-zipper motif. The resulting analogs were named CSP-1, CSP2, CSP-3, and CSP-4. Peptide structure analysis was conducted using the PEP-FOLD program (http://bioserv.rpbs.univ-paris-diderot.fr/ services/PEP-FOLD/). (C) CSP showed peptide-peptide interactions as in a leucine zipper motif. (D) CSP-4 structure showed disruption of the repeat leucine and/or isoleucine zipper motif. 
Table 1: The antibiotic activity of clavaspirin, its analogue peptides and melittin, erythromycin, gentamicin, ampicillin and piperacidin

\begin{tabular}{|c|c|c|c|c|c|c|c|c|c|c|c|c|c|c|c|}
\hline \multirow{3}{*}{$\begin{array}{l}\text { Microorganism } \\
\text { strains }\end{array}$} & \multicolumn{15}{|c|}{$\mathrm{MIC}(\mu \mathrm{M})$} \\
\hline & \multicolumn{2}{|c|}{ Cla } & \multicolumn{2}{|c|}{ CSP-1 } & \multicolumn{2}{|c|}{ CSP-2 } & \multicolumn{2}{|c|}{ CSP-3 } & \multicolumn{2}{|c|}{ CSP-4 } & \multirow[t]{2}{*}{ Me } & \multirow[t]{2}{*}{$\mathbf{E r}$} & \multirow[t]{2}{*}{ Ge } & \multirow[t]{2}{*}{ Am } & \multirow[t]{2}{*}{$\mathbf{P i}$} \\
\hline & I & II & I & II & $\mathbf{I}$ & II & I & II & I & II & & & & & \\
\hline \multicolumn{16}{|l|}{ Gram (-) } \\
\hline E. coli & 2 & 64 & 4 & 8 & 2 & 4 & 2 & 4 & 2 & 4 & 2 & - & - & - & - \\
\hline P. aeruginosa & 32 & $>64$ & 32 & 32 & 32 & 16 & 32 & 32 & 32 & 32 & 2 & - & - & - & - \\
\hline L. monocytogenes & 16 & 64 & 16 & 64 & 8 & 4 & 16 & 8 & 4 & 4 & 2 & - & - & - & - \\
\hline \multicolumn{16}{|l|}{ Gram (+) } \\
\hline B. subtilis & 16 & 64 & 16 & 64 & 4 & 4 & 8 & 16 & 4 & 4 & 2 & - & - & - & - \\
\hline S. epidermidis & 4 & 32 & 4 & 16 & 4 & 32 & 4 & 8 & 4 & 8 & 2 & - & - & - & - \\
\hline S. aureus & 16 & 64 & 16 & 64 & 8 & 16 & 8 & 8 & 8 & 8 & 2 & - & - & - & - \\
\hline S. typhimurium & 32 & 64 & 32 & 64 & 64 & 4 & 64 & 4 & 64 & 4 & 2 & - & - & - & - \\
\hline P. vulgaris & 8 & 64 & 8 & 64 & 4 & 8 & 4 & 8 & 4 & 8 & 2 & - & - & - & - \\
\hline \multicolumn{16}{|l|}{ Resistant } \\
\hline $\begin{array}{l}\text { E. coli } \\
\text { CCARM } 1238\end{array}$ & - & - & - & - & - & - & - & - & - & 2 & 2 & - & - & $>800$ & $>800$ \\
\hline P. aeruginosa 3543 & - & - & - & - & - & - & - & - & - & 4 & 2 & - & - & $>800$ & $>800$ \\
\hline P. aeruginosa 3904 & - & - & - & - & - & - & - & - & - & 2 & 2 & - & - & $>800$ & $>800$ \\
\hline P. aeruginosa 3547 & - & - & - & - & - & - & - & - & - & 4 & 2 & - & - & 400 & 200 \\
\hline P. aeruginosa 4007 & - & - & - & - & - & - & - & - & - & 2 & 2 & - & - & $>800$ & $>800$ \\
\hline S. aureus 3126 & - & - & - & - & - & - & - & - & - & 8 & 2 & 128 & 32 & - & - \\
\hline S. aureus 0027 & - & - & - & - & - & - & - & - & - & 8 & 2 & $>256$ & 64 & - & - \\
\hline S. aureus 5157 & - & - & - & - & - & - & - & - & - & 8 & 2 & 16 & 16 & - & - \\
\hline S. aureus 1635 & - & - & - & - & - & - & - & - & - & 8 & 2 & $>256$ & $>256$ & - & - \\
\hline S. aureus 4761 & - & - & - & - & - & - & - & - & - & 8 & 4 & $>256$ & 32 & - & - \\
\hline S. aureus 5159 & - & - & - & - & - & - & - & - & - & 8 & 8 & 16 & 16 & - & - \\
\hline S. aureus 3359 & - & - & - & - & - & - & - & - & - & 8 & 4 & $>256$ & 64 & - & - \\
\hline S. aureus 2122 & - & - & - & - & - & - & - & - & - & 8 & 4 & $>256$ & 128 & - & - \\
\hline S. aureus 1630 & - & - & - & - & - & - & - & - & - & 8 & 4 & $>256$ & 64 & - & - \\
\hline S. aureus 1870 & - & - & - & - & - & - & - & - & - & 8 & 4 & $>256$ & 16 & - & - \\
\hline S. aureus 3511 & - & - & - & - & - & - & - & - & - & 8 & 4 & $>256$ & $>256$ & - & - \\
\hline S. aureus 5156 & - & - & - & - & - & - & - & - & - & 8 & 4 & $>256$ & $>256$ & - & - \\
\hline S. aureus 3518 & - & - & - & - & - & - & - & - & - & 8 & 4 & $>256$ & $>256$ & - & - \\
\hline
\end{tabular}

Minimum inhibitory concentrations (MIC) were determined in $10 \mathrm{mM}$ sodium phosphate buffer (I, pH 5.5; and II, pH 7.4) containing 10\% Luria broth (LB). Drug-resistant Pseudomonas aeruginosa and Staphylococcus aureus bacteria were isolated from hospitalized otitis media patients (Chonnam National University's hospital, Korea). This strain (with CCARM number) was obtained from the Culture Collection of Antimicrobial Resistant Microbes in Korea. Cla, Me, Er, Ge, AM and Pi are Clavaspirin, Melittin, erythromycin, gentamicin, ampicillin and piperacidin, respectively. $(-)$ is not determined.

lipopolysaccharide (LPS) prompted us to test whether CSP4 suppressed the inflammatory response elicited by LPS or lipoteichoic acid (LTA). CSP-4 similarly reduced TNF- $\alpha$ and IL-1 $\beta$ levels in RAW 264.7 cells treated with $1 \mu \mathrm{g} / \mathrm{mL}$ S. aureus LTA (Figure 3D). In the absence of CSP-4, TNF- $\alpha$ and IL-1 $\beta$ were predominantly localized to the cytosol, but were absent from cells treated with $100 \mu \mathrm{g} / \mathrm{mL}$ CSP4. Thus, CSP-4 not only exerts antimicrobial effects, but also inhibits the production of pro-inflammatory cytokines during S. aureus CCARM 0027 infection.

\section{In vivo efficacy}

We used S. aureus CCARM 0027-infected hairless mice as a model of dermal infection and inflammation.
S. aureus CCARM 0027 induced skin inflammation and caused histological changes (Figure 4A). Hematoxylin and eosin-stained sections showed that the epidermis of infected mice was thicker than that of PBS-treated controls or mice inoculated with $200 \mu \mathrm{g} / \mathrm{mL} \mathrm{CSP}-4$ alone. Moreover, immune cells infiltrated the epidermis of $S$. aureus CCARM 0027-infected mice. CSP-4 (at $200 \mu \mathrm{g} / \mathrm{mL}$ and $100 \mu \mathrm{g} / \mathrm{mL}$ ) elicited a dose-dependent decrease in epidermal thickness and immune cell infiltration. Immunohistochemical analysis with fluorescein isothiocyanate (FITC)-labeled anti-TNF- $\alpha$, anti-IL-1 $\beta$, and anti-TLR-2 antibodies revealed that skin samples from mice infected with $S$. aureus CCARM 0027 without CSP-4 contained significantly higher levels of proinflammatory cytokines and TLR-2 than infected mice 
treated with $100 \mu \mathrm{g} / \mathrm{mL}$ or $200 \mu \mathrm{g} / \mathrm{mL}$ CSP-4. Western blot analysis showed that the $S$. aureus membranes contained LTA, which is thought to bind to TLR-2 on immune cells such as macrophages, activating innate immunity in response to gram-positive pathogen recognition. This, in turn, activated NF- $\kappa \mathrm{B}$ signaling and induced TNF- $\alpha$, IL$1 \beta$, and cathelicidin production to form a line of defense against infectious microorganisms (Figure 4B). However, mice treated with $200 \mu \mathrm{g} / \mathrm{mL}$ or $100 \mu \mathrm{g} / \mathrm{mL} \mathrm{CSP}-4$ showed concentration-dependent decreases in TLR-2, NF- $\kappa \mathrm{B}$, TNF- $\alpha$, IL- $1 \beta$, and cathelicidin levels. Examination of dermal collagen and elastin using scanning electron microscopy (SEM) showed that in skin sections from mice treated with PBS or CSP-4 alone, the dermal collagen and elastin were not damaged, whereas the skin of $S$. aureus CCARM 0027-infected mice showed substantial collagen and elastin damage that was dose-dependently reduced by CSP-4 (Figure 4C). This data suggests that the skin of $S$. aureus CCARM 0027-infected hairless mice undergoes morphological and immunohistochemical changes indicated by inflammation, and that CSP-4 greatly attenuates that response.

\section{Distribution of topically applied CSP-4 on the skin}

CSP-4 will be applied to the skin topically from induced dermatitis against $S$. aureus CCARM 0027. Using

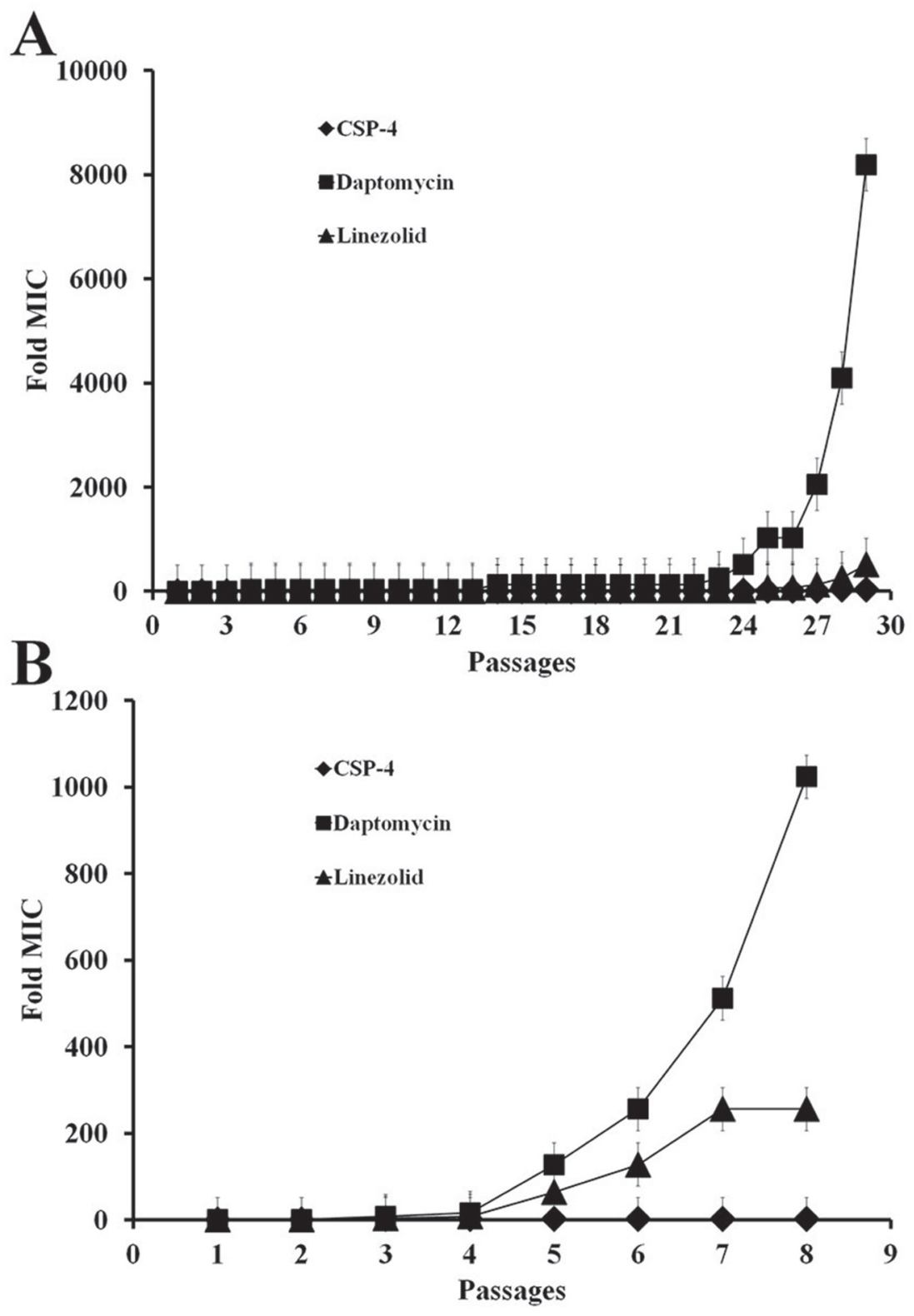

Figure 2: CSP and its analogues on the bacterial cell membrane do not lead to antibiotic resistance. (A, B) Development of resistance in S. aureus CCARM 29213 cells exposed to CSP-4, daptomycin, or linezolid at pH 5.5 and pH 7.4. The Y-axis shows the relative change in MIC from the first passage. All values represent the mean \pm SD of three individual experiments $(p<0.05$, one-way ANOVA). 
fluorescence microscopy with rhodamine-labeled CSP-4, we observed that the topically applied peptide permeated into deep layers of the skin. Fluorescence was detected at skin depths of 25-40 $\mu \mathrm{m}$. The fluorescent signal was detected throughout the epidermis within approximately $15 \mathrm{~min}$ and then throughout the dermis within $30 \mathrm{~min}$. This result demonstrates that topically applied CSP-4 is rapidly distributed deep into infected skin (Figure 4D and Supplementary Figure 2).

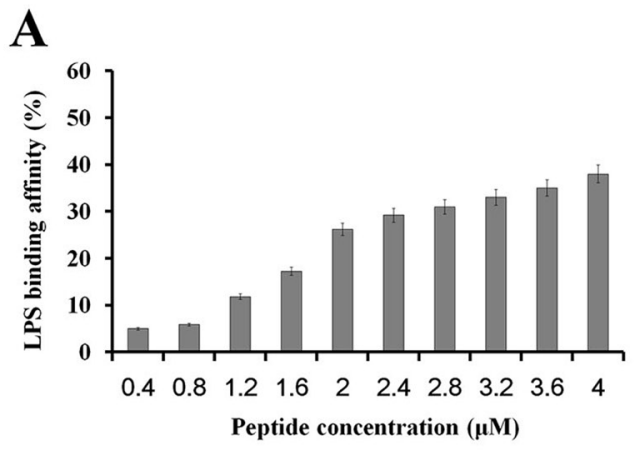

\section{Mechanism of action}

We used light scattering to analyze the selfaggregation of CSP and its analogues (Figure 5). Although CSP and CSP-1 aggregated in a dose-dependent manner at $\mathrm{pH} 7.4, \mathrm{CSP}-4$ showed very little self-aggregation at $\mathrm{pH} 5.5$ or $\mathrm{pH} 7.4$ (Figure 5A and Figure 5D). Given that CSP-4 is less hydrophobic than other CSP analogues, we suggest that the increased antimicrobial activity

\section{B}
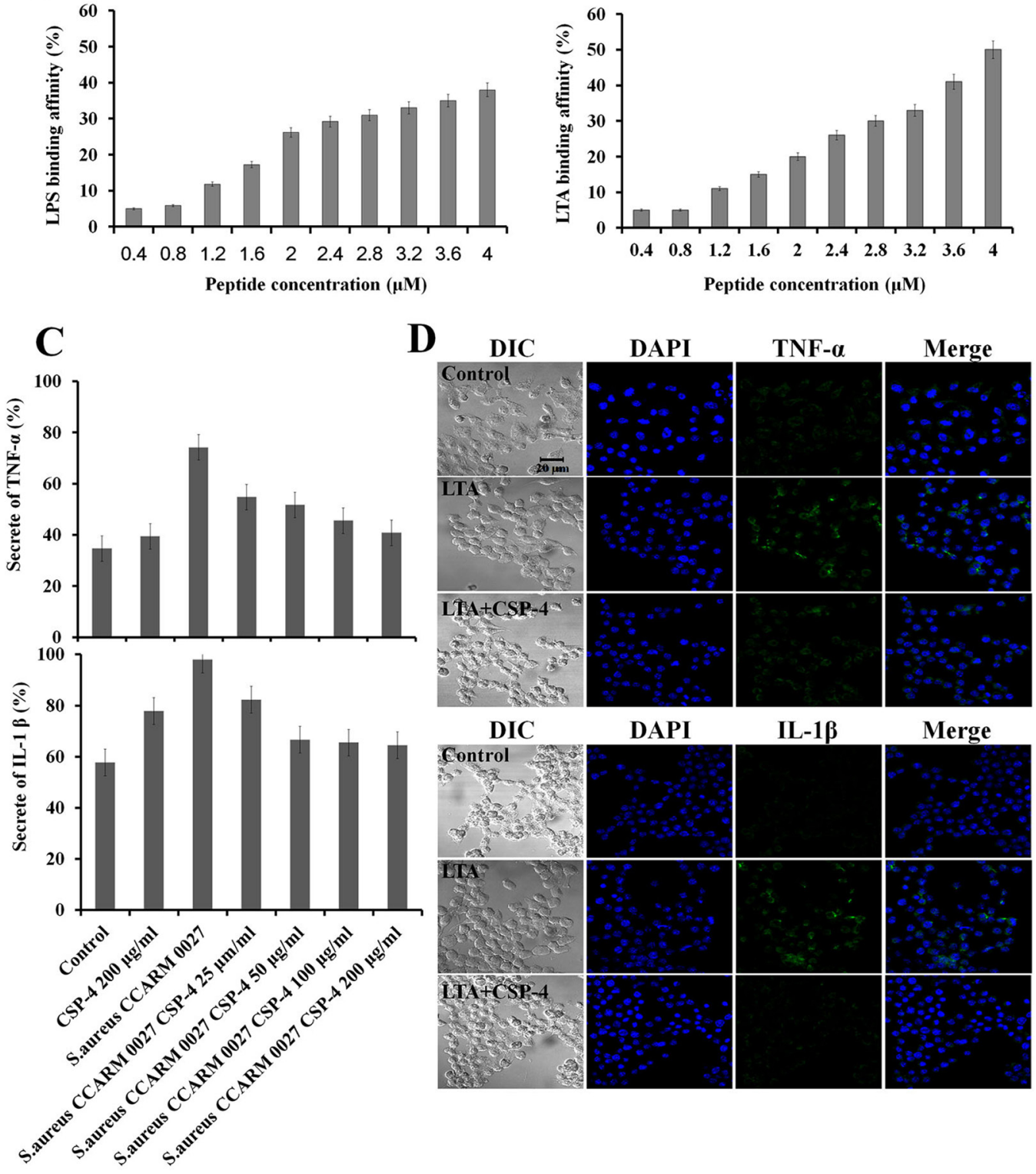

Figure 3: Binding of CSP-4 to LPS and LTA and CSP-4-induced inhibition of pro-inflammatory cytokines in RAW 264.7 macrophages. (A, B) CSP-4 binding at the indicated concentrations to E. coli LPS in 5 mM HEPES buffer, as measured using 2.5 $\mu \mathrm{M}$ dansyl polymyxin B $(E x .340 \mathrm{~nm}, E m .485 \mathrm{~nm})$. All values represent the mean $\pm \mathrm{SD}$ of three individual experiments $(p<0.05$, one-way ANOVA). (C) Secretion of TNF- $\alpha$ (top) and IL-1 $\beta$ (bottom) from RAW 264.7 cells exposed to $S$. aureus CCARM $0027\left(1 \times 10^{6} \mathrm{cfu} / \mathrm{mL}\right)$ and subsequently treated with CSP-4 $(25,50,100$, and $200 \mu \mathrm{g} / \mathrm{mL})$. All values represent the mean \pm SD of three individual experiments $(p$ $<0.05$, one-way ANOVA). (D) The effect of CSP-4 $(100 \mu \mathrm{g} / \mathrm{mL})$ on $S$. aureus LTA-induced expression of TNF- $\alpha$ and IL-1 $\beta$ in RAW 264.7 macrophages. The cells were stimulated with LTA $(1 \mu \mathrm{g} / \mathrm{mL})$ for $3 \mathrm{~h}$ in the presence and/or absence of CSP-4 at $\mathrm{pH} 5.5$ (top) or pH 7.4 (bottom), fixed, permeabilized, and stained with antibodies. Scale bar, $20 \mu \mathrm{m}$. 
and reduced cytotoxicity were achieved by replacing hydrophobic residues with more hydrophilic residues (Supplementary Table 1). To investigate the structureactivity relationship of the peptides, we used circular dichroism (CD) spectroscopy to determine their secondary structures in aqueous solution $(10 \mathrm{mM}$ sodium phosphate at $\mathrm{pH} 5.5$ and $\mathrm{pH} 7.4)$ and a membrane-mimetic environment (30 mM SDS, $1 \% \mathrm{w} / \mathrm{v}$, at $\mathrm{pH} 5.5$ and $\mathrm{pH}$ 7.4). $\mathrm{CSP}$ and its analogs showed random coiled structures in aqueous solution at $\mathrm{pH} 5.5$ or $\mathrm{pH} 7.4$ (Figure 5B and Figure 5E), but all peptides formed $\alpha$-helical structures in the membrane-mimetic environment (Figure 5C and Figure 5F). However, CSP and CSP-1 also showed an unordered structure between 220 and $190 \mathrm{~nm}$ in both the aqueous and membrane-mimetic environments at $\mathrm{pH} 7.4$, indicating aggregation (Figure 5E).

Cationic SYTOX-Green dye does not penetrate the cell membrane unless the membrane is damaged, and its fluorescence intensity increases upon binding to intracellular nucleic acids [16]. Using SYTOX-Green to assess peptide-induced membrane disruption in E. coli and $S$. aureus (Figure 6), we found that treating bacteria with CSP-4 elicited a dose-dependent increase in fluorescence intensity, indicating rapid disruption of the bacteria cell membrane at $\mathrm{pH} 5.5$ (Figure 6A and Figure 6B) and $\mathrm{pH}$ 7.4 (Figure 6E and Figure 6F). In contrast, CSP showed
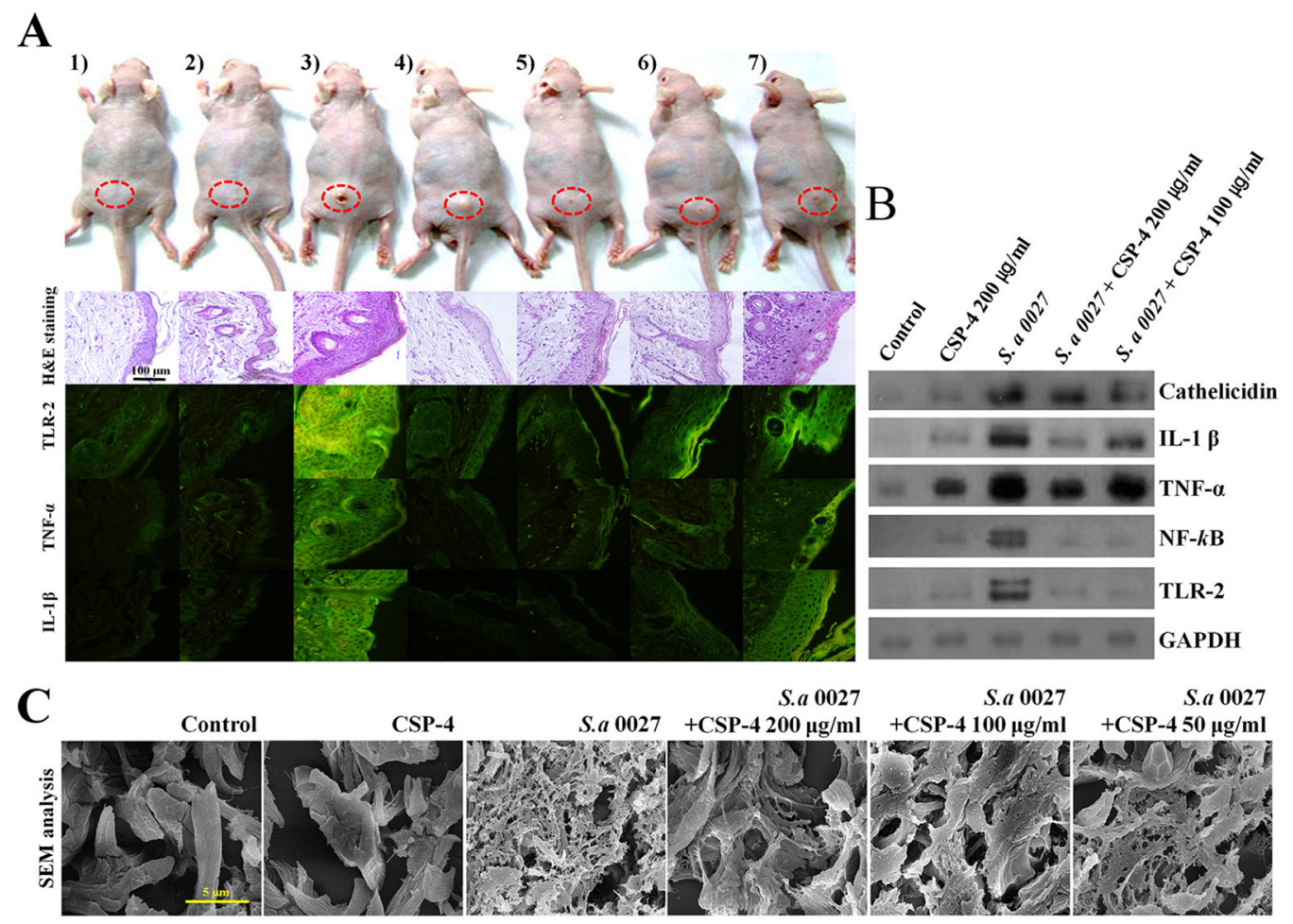

D

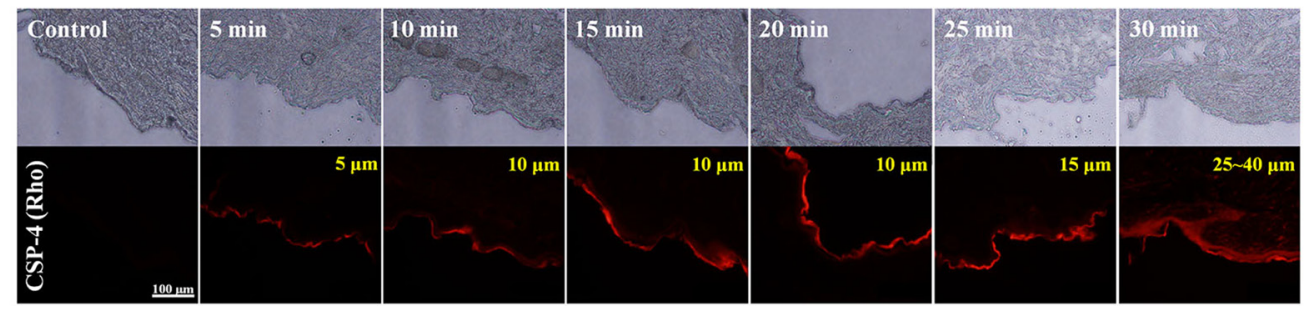

Figure 4: Application of CSP-4 to hairless mouse skin. (A) Hairless mouse skin infected with S. aureus CCARM $0027\left(1 \times 10^{8}\right.$ $\mathrm{cfu} / \mathrm{mL}$ ) leading to dermatitis. Mice were treated topically with 200, 100, 50, or $25 \mu \mathrm{g} / \mathrm{mL}$ CSP-4 and were sacrificed 7 days later. Dorsal skin tissue was collected and stained using hematoxylin and eosin or FITC-conjugated anti-TLR-2, anti-TNF- $\alpha$ and anti-IL-1 $\beta$ antibodies, as indicated. From left to right, samples were treated with 1) PBS, 2) $200 \mu \mathrm{g} / \mathrm{mL} \mathrm{CSP-4,} \mathrm{3)} \mathrm{S.} \mathrm{aureus} \mathrm{CCARM} 0027 \mathrm{at} 1 \times 10^{8} \mathrm{cfu} / \mathrm{mL}, 4$ ) $S$. aureus and $200 \mu \mathrm{g} / \mathrm{mL}$ CSP-4, 5) S. aureus and $100 \mu \mathrm{g} / \mathrm{mL}$ CSP-4, 6) S. aureus and $50 \mu \mathrm{g} / \mathrm{mL}$ CSP-4, and 7) $S$. aureus and $25 \mu \mathrm{g} / \mathrm{mL}$ CSP-4. Scale bar, $100 \mu \mathrm{m}$. (B) Western blots showing the effect of CSP-4 on S. aureus CCARM 0027-induced expression of the indicated pro-inflammatory signaling proteins and AMP cathelicidin. (C) Scanning electron micrographs showing morphological changes in the dermis of the hairless mouse under the indicated conditions. S. aureus CCARM 0027 was added at $1 \times 10^{8} \mathrm{cfu} / \mathrm{mL}$. Scale bar, $5 \mu \mathrm{m}$. (D) Time-dependent penetration of hairless mouse skin by rhodamine-labeled CSP-4 (red; $200 \mu \mathrm{g} / \mathrm{mL}$ ). Scale bars, $100 \mu \mathrm{m}$. Numbers in the upper right of the fluorescence micrographs indicate depth of penetration. 
little ability to disrupt bacterial membranes at $\mathrm{pH}$ 7.4. Measurement of DisC3-5 fluorescence confirmed the dose-dependent disruption and resultant depolarization of the $E$. coli membrane by CSP-4 (Figure 6C).

The killing kinetics for CSP and CSP-4 against $E$. coli at $\mathrm{pH} 5.5$ and $\mathrm{pH} 7.4$ indicated that $\mathrm{CSP}-4$ reduced bacterial growth faster than CSP at their respective MICs (Figure 6D). The time-dependent depolarization of FD-FITC-dextran-loaded large unilamellar vesicles (LUVs) suggests that cells treated with CSP-4 were more depolarized at $\mathrm{pH} 7.4$ than at $\mathrm{pH} 5.5$ (Figure 6G). The CSP-4 peptide is dose-defendant increased of membrane disruption on $S$. aureus membrane (Figure $6 \mathrm{H}$ ).

We investigated the mechanism of action of the CSP analogs using confocal laser scanning microscopy with tetramethylrhodamine-labeled peptides at their MICs. Tetramethylrhodamine-labeled CSP-2, CSP-3, and CSP-4 were observed on $E$. coli cell surfaces at $\mathrm{pH} 5.5$ and $\mathrm{pH} 7.4$ (Figure 7A). Electron microscopic examination revealed that after binding to the membrane, CSP-4 at its MIC induced membrane damage in both $E$. coli and $S$. aureus cells at $\mathrm{pH} 5.5$ and $\mathrm{pH} 7.4$ (Figure 7C-7E). The lytic activities of the CSP analogues were further examined using giant unilamellar vesicles (GUVs) composed of PE/ PG/PE-rhodamine (69/30/1), which were visualized and recorded using a CCD camera. Treatment with $20 \mu \mathrm{M}$ CSP induced lysis of the GUVs at $\mathrm{pH} 5.5$, but not at $\mathrm{pH}$ 7.4. In contrast, $20 \mu \mathrm{M}$ concentrations of all CSP analogs induced lysis of the GUV membrane at both pH 5.5 and pH 7.4. Moreover, analogues in which an isoleucine residue was substituted with lysine disrupted the GUV membrane more quickly at $\mathrm{pH} 5.5$ than at $\mathrm{pH} 7.4$ compared to those substituted with alanine (Figure 7B and Supplementary Figure 3). This data confirms that the CSP-4 peptide acts on the $S$. aureus membrane via a carpet-like mechanism, in which CSP-4 quickly interacts with the inner membrane through its electrostatic interaction with LTA.

\section{DISCUSSION}

Infectious diseases caused by various microorganisms, including antibiotic-resistant bacteria, affect a considerably large human population. In particular, dermatitis infections such as those caused by S. aureus are a serious problem in hospitals. These types of infections have increased because of antibiotic resistance. $S$. aureus has been reported to cause serious infections of the skin and soft tissue [17] and is highly invasive, causing life-threatening complications, including bacteremia, pneumonia, abscesses of various organs, meningitis,
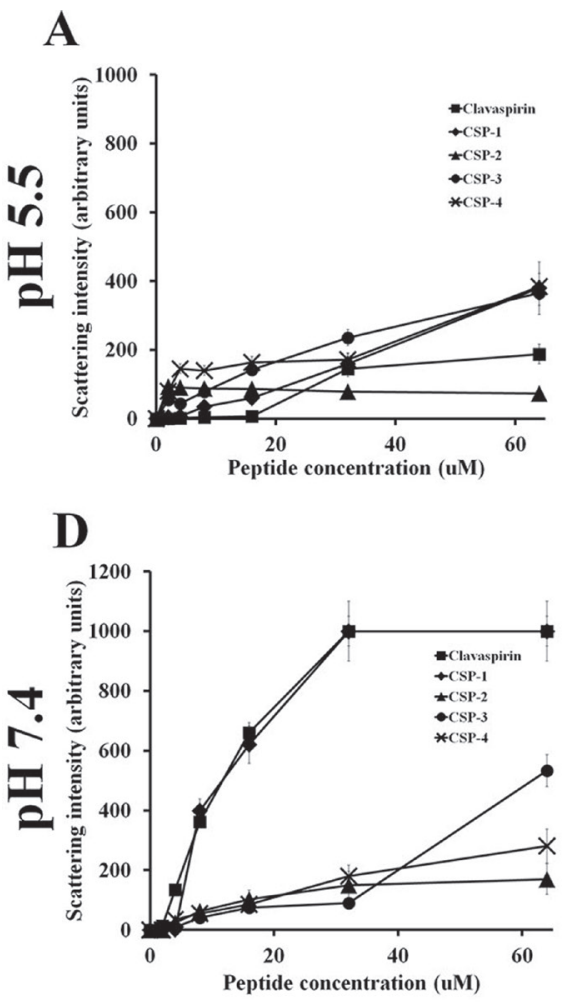
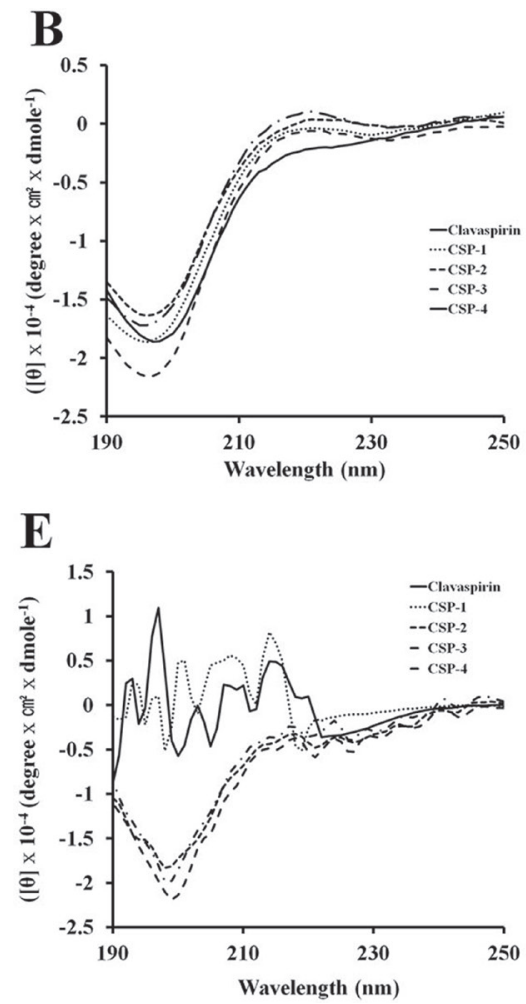
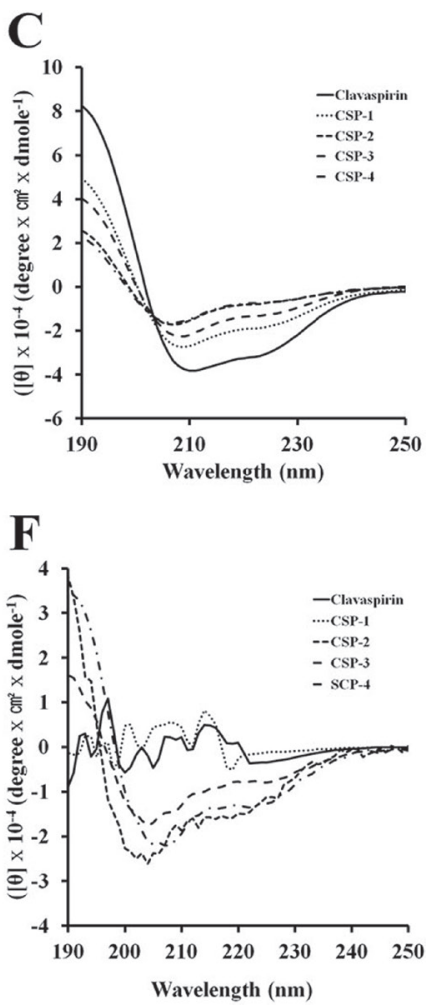

Figure 5: Aggregation of clavaspirin and its analogue peptides at pH 5.5 and pH 7.4. Aggregation of clavaspirin and its analogue peptides. (A, B) Peptides incubated for $12 \mathrm{~h}$ at room temperature in $10 \mathrm{mM}$ sodium phosphate buffer at $\mathrm{pH} 5.5 \mathrm{or} \mathrm{pH} 7.4 \mathrm{were}$ monitored for structural changes using light scattering on an LS55 luminescence spectrometer (excitation $400 \mathrm{~nm}$ and emission $400 \mathrm{~nm}$ ). Circular dichroism (CD) spectra analyses of peptides were incubated in $10 \mathrm{mM}$ sodium phosphate (D, E left panel) or $30 \mathrm{mM}$ SDS (C, F right panel). The secondary structures of CSP and its analogue peptides were determined using Far-UV CD spectra. All values represent the mean $\pm \mathrm{SD}$ of three individual experiments ( $p<0.05$, one-way ANOVA). 
osteomyelitis, endocarditis, and sepsis [18, 19]. These infections are often nosocomial, resulting from the widespread emergence of DRSA and MRSA, and are an important public health concern [2]. Thus, alternatives to conventional antibiotic drugs are urgently needed [20-22]. Previous studies of AMPs have focused on their isolation, characterization, potential mechanisms of action, and effects of amino acid substitution. Therefore, AMPs have also been studied in vivo, on tissues infected by antibioticresistant bacteria. In this study, we report a newly designed CSP-4 peptide, effective in a bacterial dermatitis mouse model infected with DRSA, non-toxic, and able to suppress the effect of various pro-inflammatory cytokines and chemokines in vivo.

CSP is an AMP with a helix-loop-helix structure that is rich in hydrophobic amino acids. CSP has leucine and isoleucine residues at positions 2, 5, 9, and 12, corresponding to the leucine and/or isoleucine zipper motif (N-terminal amino acid), which contains three isoleucine residues and one leucine residue located adjacently. In other reports, AMPs with leucine or phenylalanine zipper motifs showed high cytotoxicity [11-13, 23-26]. In the current study, we analyzed the peptide structure using the PEP-FOLD program (http://bioserv.rpbs.univ-parisdiderot.fr/services/PEP-FOLD/). CSP showed peptidepeptide interactions (N-terminal region) driven by the leucine zipper motif (Figure 1A and Figure 1C). Therefore, to reduce hydrophobicity, leucine and/or isoleucine in the zipper motif (N-terminal region) were substituted with alanine or lysine residues; these substituted CSPs showed little or no cytotoxicity and maintained activity. CSP-4 was developed by substituting lysine for the isoleucine residues at positions 9 and 12. The CSP-4 structure disrupts the repeat leucine and/or isoleucine zipper motif at the N-terminal (Figure 1B and Figure 1D). This structure is a key determinant of the hemolytic and cytotoxic properties of the peptide, as CSP-4 exhibited potent antimicrobial activity against both drug-susceptible reference strains and multidrug-resistant bacterial strains (Table 1) while showing remarkably low cytotoxicity in hRBCs and mammalian cells (Supplementary Table 1 and Supplementary Figure 1). This result was observed because of the low hydrophobic peptide-peptide interaction or aggregation by substitution of isoleucine to
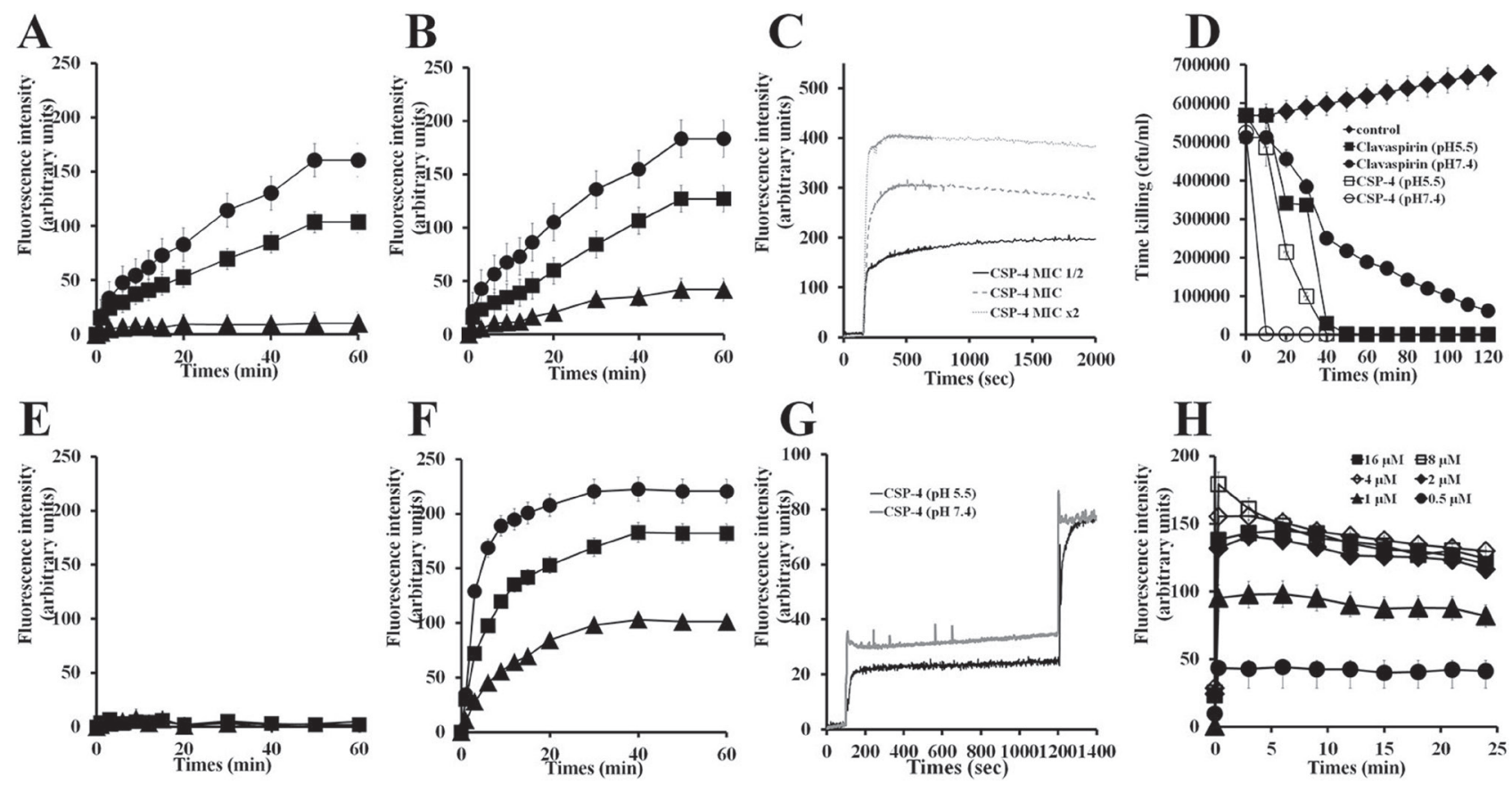

Figure 6: Mechanism of action of CSP and its analogue peptides against $\boldsymbol{E}$. coli and $\boldsymbol{S}$. aureus. E. coli $\left(2 \times 10^{7} \mathrm{cfu} / \mathrm{mL}\right)$ were incubated with $1 \mu \mathrm{M}$ SYTOX-Green for $15 \mathrm{~min}$. CSP $(\mathbf{A}, \mathbf{E})$ and CSP-4 $(\mathbf{B}, \mathbf{F})$ were added when basal fluorescence reached a constant value in $10 \mathrm{mM}$ sodium phosphate buffer at $\mathrm{pH} 5.5$ (A, B) or pH 7.4 (E, F). (C) Fluorescence was monitored at the indicated times $($ Ex. $485 \mathrm{~nm}$ and $E m .520 \mathrm{~nm})$. Hyperpolarization was induced by incubation for $5 \mathrm{~min}$ on ice followed by incubation at $37^{\circ} \mathrm{C}$ with disC $-5(0.5 \mathrm{mM})$ for 10 min. (D) CSP-4 killing kinetics. E. coli cells in not a growth phase were adjusted to $\mathrm{OD}_{600} 0.06$, CSP-4 was then added at its MIC or $2 \times$ $\mathrm{MIC}$, and changes in fluorescence were monitored continuously (Ex. $622 \mathrm{~nm}$ and Em. $670 \mathrm{~nm}$ ) and plotted as arbitrary units. (G) CSP-4induced release of FD-FITC-dextran from LUV liposomes (PE/PG, 7/3, w/w). Effect of pH on CSP-4-induced release of FD-FITC-dextran from LUV liposomes (PE/PG, 7/3, w/w). CSP-4 was added at the MIC to LUVs entrapping FD-FITC-dextran (100 mg/mL) dye in HEPES buffer at $\mathrm{pH} 5.5$ or $\mathrm{pH}$ 7.4. The dotted line shows the simultaneous determinations of bacterial viability after exposure of $E$. coli cell to the MIC or $2 \times$ MIC of CSP-4. (H) Effect of CSP-4 on S. aureus membrane permeability. S. aureus cells $\left(2 \times 10^{7} \mathrm{cfu} / \mathrm{mL}\right)$ were incubated for 15 min with $1 \mu \mathrm{M}$ SYTOX-Green. CSP-4 was added when basal fluorescence reached a constant value in $10 \mathrm{mM}$ sodium phosphate buffer. The increase in fluorescence was monitored at the indicated times $(E x .485 \mathrm{~nm}$ and $E m .520 \mathrm{~nm})$. All values represent the mean \pm SD of three individual experiments ( $p<0.05$, one-way ANOVA). 
lysine (Figure 1B, Figure 1D and Figure 5). CSP, CSP1 , and CSP-3 peptides induced higher self-aggregation, resulting from hydrophobic interactions (induced by the leucine zipper motif), at $\mathrm{pH} 5.5$ and $\mathrm{pH} 7.4$, but not the CSP-2 and CSP-4 peptides. CSP induced low aggregation at pH 5.5 (Figure 5A); however, aggregation increased at pH 7.4 (CSP, CSP-1 and CSP-3) (Figure 5D). The CSP2 and CSP-4 analogue were not affected (Figure 5A and Figure 5D) by varying the $\mathrm{pH}$. Additionally, we analyzed the changes in secondary structure using $\mathrm{CD}$ spectra. CSP showed a helical structure in SDS buffer (Figure 5C), but not in $10 \mathrm{mM}$ sodium phosphate buffer at $\mathrm{pH}$ 5.5 (Figure 5F). However, CSP showed high aggregation in SDS buffer and $10 \mathrm{mM}$ sodium phosphate buffer at pH 7.4 (Figure 5E). CSP-2, CSP-3, and CSP-4 formed stable helical structures within/without $30 \mathrm{mM}$ SDS at pH 5.5 and pH 7.4 (Figure 5C and Figure 5F). CSP-4, with its dissociated leucine zipper motif, showed strong antimicrobial activity against DRSA and no or low cytotoxicity in hRBC and $\mathrm{HaCaT}$ cells, independent or regardless of $\mathrm{pH}$ (Table 1, Supplementary Table 1, and Supplementary Figure 1).

An increasing number of studies have reported the emergence of daptomycin or linezolid-nonsusceptible
$S$. aureus in patients during daptomycin therapy. $S$. aureus is an important human pathogen responsible for numerous infections. Therefore, we used either CSP-4, daptomycin, or linezolid to treat $S$. aureus infections. We observed that, following prolonged exposure, the MIC of daptomycin against $S$. aureus increased by as much as 8000 -fold, and that of linezolid was also greatly increased (Figure 2). Therefore, we concluded that these bacterial cells had developed resistance to both daptomycin and linezolid over a relatively short period of time, but not to CSP-4 at pH 5.5 (Figure 2A) and pH 7.4 (Figure 2B). The resistance to daptomycin $(0.25 \mu \mathrm{M}$ MIC) and linezolid (4 $\mu \mathrm{M}$ MIC) was induced throughout 24 passages under the same conditions at $\mathrm{pH} 5.5$ (Figure 2A), while at $\mathrm{pH}$ 7.4, daptomycin (4 $\mu \mathrm{M}$ MIC) and linezolid ( $8 \mu \mathrm{M}$ MIC) induced resistance after only 5 passages (Figure 2B). This finding suggests that bacterial cells do not develop resistance to CSP-4 as rapidly as they do to conventional antibiotics (such as daptomycin and linezolid).

The outer membrane of gram-positive bacteria contains LTA, which is secreted during cell division and is recognized by TLR-2 on immune cells via interactions with LTA-binding protein (Figure 3B). Upon LTA recognition (e.g., in diseases such as colonization and
A

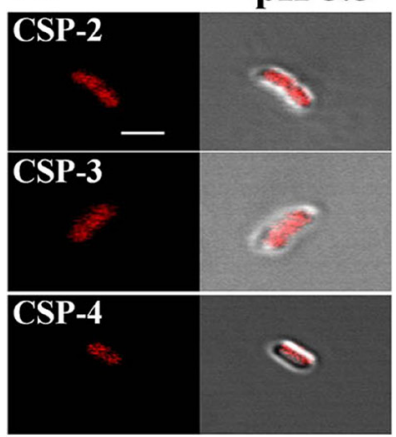

pH 7.4

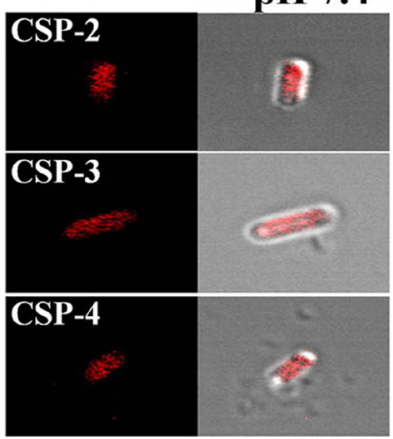

B
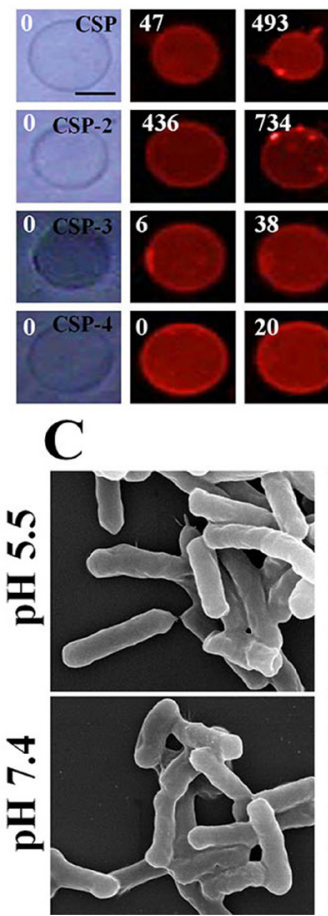

pH 5.5
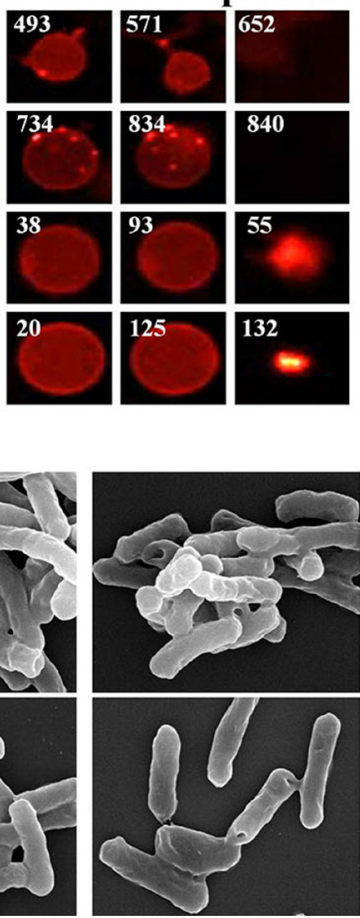

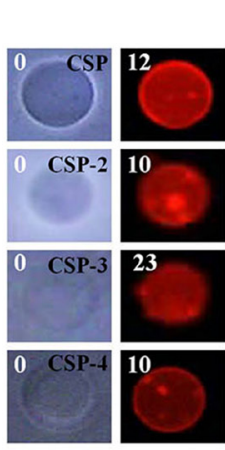

D

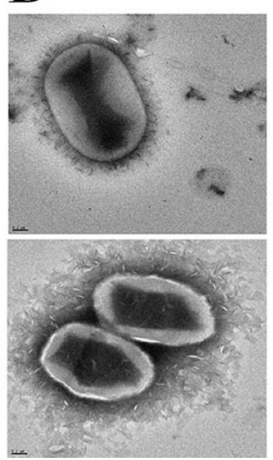

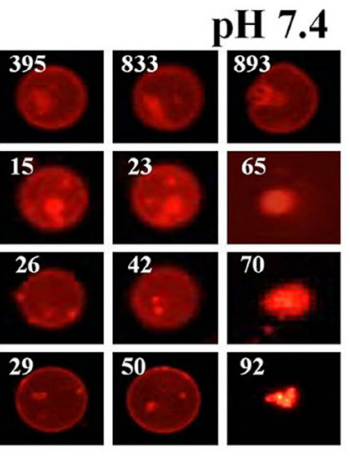

$\mathbf{E}$

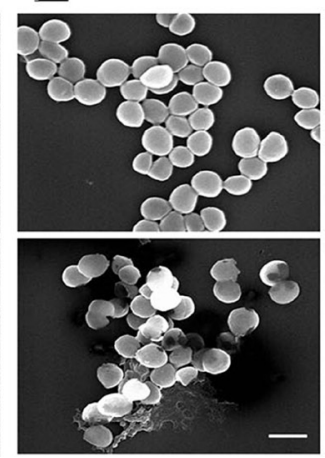

Figure 7: Accumulation of CSP and its analogues on the bacterial cell membrane. (A) Localization of the indicated CSP analogues on E. coli. Cells were incubated for $20 \mathrm{~min}$ with the MICs of rhodamine-labeled AMPs. Cells were visualized using confocal laser scanning microscopy. Scale bar, $5 \mu \mathrm{m}$. (B) Effect of CSP $(20 \mu \mathrm{M}$; pH 5.5 or pH 7.4) and the indicated CSP analogues on GUVs (PE/ $\mathrm{PG} / \mathrm{PE}$-rhodamine). Scale bar, $50 \mu \mathrm{m}$. Scanning $(\mathbf{C}, \mathbf{E})$ and transmission (D) electron micrographs show disruption of the $E$. coli and $S$. aureus cell membrane by CSP-4 at 1/2 MIC in $10 \mathrm{mM}$ sodium phosphate buffer ( $\mathrm{pH} 5.5$ and $\mathrm{pH} 7.4$ ). The panels show formation of large pores after exposure to CSP-4. S. aureus cells were cultured in the absence (top) and presence (bottom) of CSP-4. Scale bar in C and E, 5 $\mu \mathrm{m}$; scale bar in d, $2 \mathrm{~nm}$. 
infection of the skin), the NF- $\kappa \mathrm{B}$ signaling pathway is activated, leading to the expression of various proinflammatory cytokines (TNF- $\alpha$ and IL-1 $1 \beta$ ). We found that the levels of signaling proteins (TLR2 and NF- $\mathrm{kB}$ ) and pro-inflammatory cytokines (TNF- $\alpha$ and IL-1 $\beta$ ) in skin tissue were lower following treatment with $100 \mu \mathrm{g} / \mathrm{mL}$ or $200 \mu \mathrm{g} / \mathrm{mL}$ CSP-4 than in untreated mice. CSP-4 appeared to neutralize LTA on the membrane of DRSA cells, downregulating the expression of pro-inflammatory cytokines (Figure 3C, Figure 4A and Figure 4B). In addition, the outer membrane of gram-negative bacteria contains LPS, which is secreted during cell division and is recognized by TLR-4 on immune cells via interactions with LPS-binding proteins (Figure 3A). A similar effect was caused by CSP4 when RAW 264.7 macrophages were treated with $1 \mu \mathrm{g} /$ $\mathrm{mL}$ S. aureus LTA (Figure 3D). Thus, CSP-4 appears to have both antimicrobial and anti-inflammatory effects.

We examined the in vivo effects of CSP-4 using a mouse model of bacterial dermatitis. CSP-4 reduced the number of FITC-conjugated anti-TLR-2, anti-TNF- $\alpha$, and anti-IL-1 $\beta$ antibodies in the skin of nude mice, indicating that the peptide achieved good penetration of the skin, enabling it to exert its bactericidal effect (Figure 4A). In addition, seven days after dermal infection with DRSA CCARM 0027, the epidermis and dermis of otherwise untreated hairless mice were swollen and damaged, reflecting infiltration by macrophages and disruption of dermal collagen and elastin. In mice that also received CSP-4, however, skin damage was substantially reduced, suggesting that CSP-4 suppresses inflammatory responses in vivo (Figure $4 \mathrm{C}$ ).

TLRs recognize specific patterns of pathogen components of bacteria, viruses, fungi, and parasites. The cell wall of gram-positive bacteria contains LTA as an important pro-inflammatory constituent, which stimulates immune cells by activating TLR-2 [27]. This signaling occurs through the myeloid differentiation primary response gene 88-dependent pathway, which leads to the downstream activation of NF-kB and mitogen-associated protein kinase signaling pathways (ERK-CREB, JNKAP-1, and p38). This signaling is responsible for the induction of pro-inflammatory cytokines, chemokines, AMPs, and adhesion molecules [28]. Previous reports have shown that keratinocytes as well as macrophages and other immune cells in the epidermis and dermis secrete AMP cathelicidin during infections, and that bacteriostatic or bactericidal activities towards pathogens such as $S$. aureus involve $\alpha$ - and $\beta$-defensins, RNase7, and dermicidin [29-33]. In the present study, S. aureus CCARM 0027 infection led to significant increases in cathelicidin levels, but the increase was attenuated by $200 \mu \mathrm{g} / \mathrm{mL}$ or $100 \mu \mathrm{g} / \mathrm{mL}$ CSP-4, again demonstrating its capacity to reduce inflammation (Figure 4B).

Recently, the HIV-TAT PTD-coupled RP-1 fusion protein was shown to penetrate the dermis when applied to the surface of rat skin [24]. We hypothesized that CSP-4 could be induced to similarly distribute into the epidermis and dermis if applied to the skin surface. We found that the peptide was predominantly localized in the epidermis after $5 \mathrm{~min}$, but after $15 \mathrm{~min}$ CSP-4 had begun to penetrate the dermis, and substantial distribution into the dermis was observed within $30 \mathrm{~min}$ (Figure 4D). The topical use of peptides has been widely studied because of its importance for treating skin diseases, and there is growing interest in using peptide application as a topical vaccination to treat skin conditions. For instance, Rothbard et al. [34] were the first to report that direct delivery of peptide R7 (polyarginine-7) into the skin leads to therapeutically effective and dose-dependent drug distribution, showing the presence of activity both in vitro and in vivo [34].

Additionally, we confirmed the mode of action of CSP-4 in bacteria. The hydrophobicity of the designed peptides, analyzed based on retention time using $\mathrm{C}_{18}$ reversed-phase high-performance liquid chromatography, was significantly reduced. The peptide analogs showed a significant reduction in aggregation at $\mathrm{pH} 7.4$, whereas CSP aggregated in a concentration-dependent manner (Figure 5D). Because hemolysis and cytotoxicity were

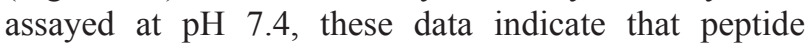
aggregation contributes to cytotoxicity at that $\mathrm{pH}$. The hydrophobicity of aggregated peptides was markedly increased. This aggregation was observed in the CD spectra at pH 7.4 [35] (Figure 5E). CSP-4 showed potent antimicrobial activity and reduced cytotoxicity in $\mathrm{HaCaT}$ and hRBC cells (Table 1 and Supplementary Table 1). The protein displayed a random coil structure and its $\alpha$-helical structure was induced in $30 \mathrm{mM}$ SDS buffer at $\mathrm{pH} 5.5$ and $\mathrm{pH} 7.4$ (Figure 5). CSP-4 possesses four histidine residues and has an increased cationic charge at $\mathrm{pH} 5.5$ because of histidine's pKa of 6.03 [36, 37]. Although its high cationicity allows CSP-4 to rapidly bind to anionic bacterial membranes through electrostatic interactions (such as LPS and LTA), this strong binding prevents easy permeation into the lipid bilayer. The leucine zipper motif-containing CSP was modified into a more hydrophilic peptide by substituting lysine for isoleucine residues (Figure 1). As a result, the CSP-4 analog not only showed reduced cytotoxicity because of disaggregation, but also showed enhanced antibacterial activity at $\mathrm{pH} 7.4$ compared to CSP (Table 1 and Supplementary Table 1).

In the present study, measurements of SYTOXGreen uptake, membrane depolarization, kill kinetics, and FITC leakage all indicated that CSP-4 exerted a rapid membranolytic effect. The difference in action of CSP-4 between $\mathrm{pH} 5.5$ and $\mathrm{pH} 7.4$ was purely kinetic, suggesting that peptide binding to the cell membrane is $\mathrm{pH}$-dependent, reflecting its cationicity. The high cationicity of CSP-4 enabled its rapid binding to the anionic components of the bacterial membrane (LTA and LPS) through electrostatic interactions. After binding to the outer membrane via LPS in E. coli and LTA in S. aureus (Figure 3), CSP-4 quickly induced cell lysis (Figure 6H and Figure 7E). 
We are suggesting that during CSP-4 peptide treatment, the pus formed on the skin will exhibit a rapid action mechanism on the bacterial membrane surface of S. aureus. Additionally, CSP-4 may exhibit a stronger bactericidal activity against $S$. aureus induced dermatitis when it is accumulated in the hair follicles on the skin [38]. In these conditions, the peptide initially accumulates on the bacterial membrane and an early electrostatic interaction occurs between its lysine and/or histidine amino acids and LTA. Subsequently, the peptide undergoes a hydrophobic interaction with the lipid head groups to permeabilize the $S$. aureus membrane, perhaps through a carpet-like mechanism [39]. Our SEM analysis supports this interpretation (Figure 8). Furthermore, we confirmed significantly reduced skin damage in CSP-4-treated (compare with untreated peptide) samples, which induced inflammation on the hairless mouse skin from $S$. aureus CCARM 0027. The skin represents a formidable barrier to the delivery of small- and large-molecule therapeutic agents. Hair follicles and sweat glands represent potentially efficient penetration pathways for topically applied substances. Our findings suggest that CSP-4 is a potential therapeutic AMP that can be applied topically onto skins undergoing infections caused by a wide range of MRSA.

\section{MATERIALS AND METHODS}

\section{Peptide synthesis, microorganisms, and antimicrobial activity}

The method for peptide synthesis has been described in detail previously [40]. E. coli ATCC 25922 (LB media), $P$. aeruginosa ATCC 15692 (NB+0.5\% NaCl media), Listeria monocytogenes ATCC 3710 (LB media), Staphylococcus epidermidis ATCC 12228 (LB media), and S. aureus ATCC 29213 (TSB media) were obtained from the American Type Culture Collection (Manassas, VA, USA). Bacillus subtilis KCTC 1998 (LB media), Salmonella typhimurium KCTC 1926 (NB media), and Proteus vulgaris KCTC 2433 (NB media) were obtained from the Korean Collection for Type Cultures (Jeollabukdo, Korea). E. coli CCARM 1238 was received from the Culture Collection of Antibiotic Resistant Microbes at Seoul Women's University, Korea. Drug-resistant $P$. aeruginosa 3543, 3904, 3547, and 4007 and $S$. aureus 3126, 0027, 5157, 1635, 4761, 5159, 3359, 2122, 1630, $1870,3511,5156$, and 3518 were resistant strains isolated from patients with otitis media in a Chonnam National University's hospital.

The antibacterial activities of AMPs (melittin, clavaspirin, and its analogs) and conventional antibiotic drugs (erythromycin, gentamicin, ampicillin, and piperacidin) were determined using microdilution assays. Bacterial cells were cultured at $37^{\circ} \mathrm{C}$ in appropriate culture media at $\mathrm{pH} 5.5$ or $\mathrm{pH} 7.4$ until collection during the mid-log phase and suspended in $10 \mathrm{mM}$ sodium phosphate buffer ( $\mathrm{pH} 5.5$ or $\mathrm{pH}$ 7.4) supplemented with $10 \%$ culture medium. Thereafter, $2 \times$ serial dilutions of each peptide $(0.25-128 \mu \mathrm{M})$ or antibiotic $(0.25-256$ $\mu \mathrm{M})$ were added to sterile 96-well plates, and aliquots of cell suspension $\left(5 \times 10^{5}\right.$ colony forming units $(\mathrm{cfu}) /$ $\mathrm{mL})$ were seeded into each well. The samples were then incubated at $37^{\circ} \mathrm{C}$ for $24 \mathrm{~h}$. At the end of the incubation, the minimum inhibitory concentrations (MICs) of the peptides were determined using a VERSA Max microplate reader (Molecular Devices Co., Sunnyvale, CA, USA) at a wavelength of $600 \mathrm{~nm}$. The lowest peptide concentration that completely inhibited growth was defined as the MIC. $\mathrm{MIC}$ values were calculated as the mean of 3 independent experiments conducted in triplicate $[40,41]$.

\section{Hemolysis}

Fresh human red blood cells (hRBCs) from healthy donors were centrifuged at $800 \times g$ and washed with phosphate-buffered saline (PBS) until the supernatant was clear. Twofold serial dilutions of the peptides in PBS were added to a 96-well plate, after which the hRBCs were added to obtain a final concentration of $8 \%(\mathrm{vol} /$ vol). The samples were then incubated with mild agitation for $1 \mathrm{~h}$ at $37^{\circ} \mathrm{C}$. The samples were then centrifuged at $800 \times g$ for $10 \mathrm{~min}$, and the absorbance of the supernatant was measured at $414 \mathrm{~nm}$. All the measurements were performed in triplicate, and the percentages of hemolysis were calculated using equation 1 :

$\%$ hemolysis $=\left[\left(A_{414}\right.\right.$ in peptide solution $-A_{414}$ in PBS $) /$ $\left(A_{414}\right.$ in $0.1 \%$ Triton $\mathrm{X}-100-A_{414}$ in PBS) $] \times 100(1)$

Where $100 \%$ hemolysis was defined as the absorbance measured from $\mathrm{hRBC}$ s exposed to $1 \%$ Triton $\mathrm{X}-100$ and zero hemolysis was characterized using hRBCs alone in PBS [40].

\section{Cytotoxicity}

To examine the cytotoxic effects of the peptides, HaCaT (human keratinocyte) cells were cultured in Dulbecco's modified Eagle's medium (DMEM) supplemented with antibiotics $(100 \mathrm{U} / \mathrm{ml}$ penicillin and $100 \mu \mathrm{g} / \mathrm{ml}$ streptomycin) and $10 \%$ fetal calf serum at $37^{\circ} \mathrm{C}$ in a humidified chamber under a $5 \% \mathrm{CO}_{2}$ atmosphere. Growth inhibition was evaluated using 3-(4, 5-dimethylthizol-2-yl)-2, 5-diphenyltetrazolium bromide (MTT) assays to measure cell viability. After cells were seeded into a 96-well plate at a density of $2 \times 10^{4} /$ well and incubated for $24 \mathrm{~h}$, twofold serial dilutions of each peptide in DMEM were added to the wells, and the cells were incubated for an additional $24 \mathrm{~h}$ at $37^{\circ} \mathrm{C}$. Thereafter, $10 \mu \mathrm{l}$ of MTT $(5 \mathrm{mg} / \mathrm{ml})$ was added to each well, and the plate was incubated for $4 \mathrm{~h}$. The supernatants were then removed, and $50 \mu \mathrm{l}$ of DMSO was added to each well to dissolve any remaining precipitate. Finally, the absorbance at $570 \mathrm{~nm}$ was measured using a microtiter reader [40]. 


\section{Resistance development assay}

To determine the MICs of CSP-4, a single colony of $S$. aureus ATCC 29213 was cultured at $37^{\circ} \mathrm{C}$ in tryptic soy broth, as well as daptomycin and linezolid, which served as commercial antibiotic positive controls. The final concentrations of CSP-4 ranged from 8 to $256 \mu \mathrm{M}$ at $\mathrm{pH} 5.5$ and from 8 to $16 \mu \mathrm{M}$ at $\mathrm{pH} 7.4$; daptomycin ranged from 0.25 to $2048 \mu \mathrm{M}$ at $\mathrm{pH} 5.5$ and from 4 to $4096 \mu \mathrm{M}$ at $\mathrm{pH}$ 7.4; linezolid ranged from 4 to $4096 \mu \mathrm{M}$ at $\mathrm{pH} 5.5$ and from 8 to $2048 \mu \mathrm{M}$ at $\mathrm{pH}$ 7.4. For each agent, the MIC was determined daily for 29 days at $\mathrm{pH} 5.5$ and/or for 8 days at $\mathrm{pH} 7.4$ using cells from wells containing half the MIC (1/2 MIC well). Briefly, cells from a 1/2 MIC well were suspended in an appropriate culture medium and incubated for $24 \mathrm{~h}$ at $37^{\circ} \mathrm{C}$, after which the suspensions were adjusted to $5 \times 10^{5} \mathrm{CFU} / \mathrm{mL}$ in $10 \mathrm{mM}$ sodium phosphate buffer (pH 5.5 or 7.4 ) with $10 \%$ tryptic soy broth, and mixed with agents in the same concentration ranges. All MICs were determined in duplicate [42].

\section{Peptide-LTA and LPS binding affinity assay}

Lipoteichoic acid (LTA) and lipopolysaccharide (LPS) binding affinity assays were performed using a Perkin-Elmer LS55 fluorometer (Waltham, MA, USA). $S$. aureus LTA and E. coli LPS ( $9 \mu \mathrm{g})$ were incubated with 2.5 $\mu \mathrm{M}$ dansyl-polymyxin B in $5 \mathrm{mM}$ HEPES buffer for 5-10 $\mathrm{min}$ at $\mathrm{pH}$ 7.4. The CSP-4 peptide was added in $0.4 \mu \mathrm{M}$ increments from 0.4 to $4 \mu \mathrm{M}$. The increase in fluorescence

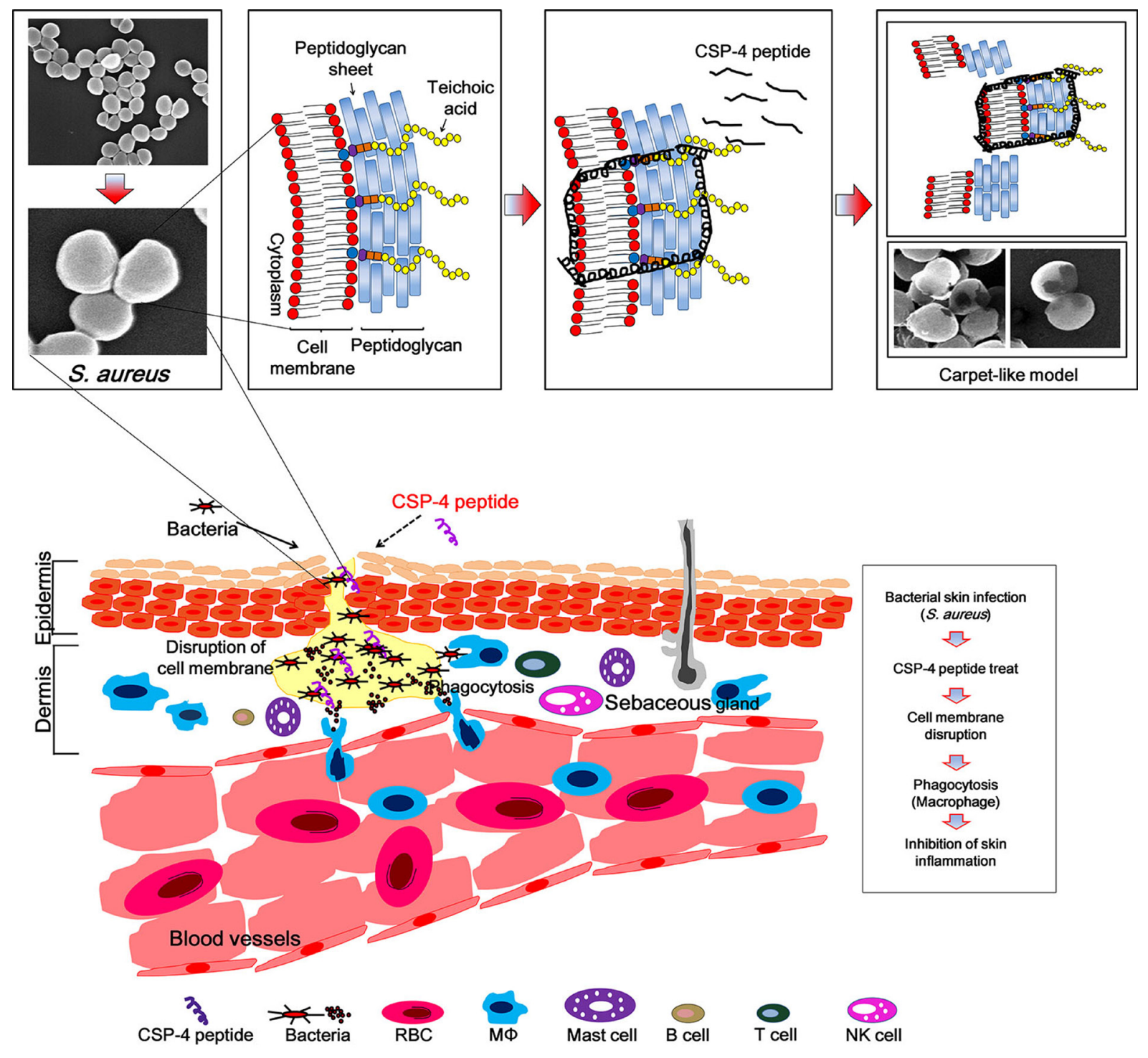

Figure 8: Schematic diagram of the proposed mechanism of action of CSP-4 based on a Toll-like receptor-mediated immune response against DRSA. CSP-4 rapidly disrupts the $S$. aureus cell membrane using a carpet-like mechanism, whereby CSP4 quickly interacts with the inner membrane through its electrostatic interaction with LTA. CSP-4 interacted with S. aureus membranes contain LTA, which binds to TLR-2 on immune cells such as macrophages. This activates the NF-kB signaling pathway and induces the production of cathelicidin and other peptides that combat microorganisms. 
intensity was assessed using a spectrofluorometer at an excitation wavelength of $340 \mathrm{~nm}$ and an emission wavelength of $482 \mathrm{~nm}$ (Perkin-Elmer LS55) [43].

\section{Cell culture and protein extraction}

To examine cytokine expression elicited by $S$. aureus CCARM 0027, RAW 264.7 mouse macrophages were cultured in DMEM supplemented with antibiotics (100 $\mathrm{U} / \mu \mathrm{M}$ penicillin and $100 \mu \mathrm{g} / \mathrm{mL}$ streptomycin) and $10 \%$ fetal calf serum in 12 -well plates at $37^{\circ} \mathrm{C}$ in a humidified chamber with an atmosphere containing $5 \% \quad \mathrm{CO}_{2}$. Expression of the pro-inflammatory cytokines TNF $\alpha$ and IL- $\beta$ was evaluated after the addition of $S$. aureus CCARM $0027\left(1 \times 10^{6} \mathrm{cfu} / \mathrm{mL}\right)$ for $30 \mathrm{~min}$ at $100^{\circ} \mathrm{C}$. After treatment, the RAW 264.7 cells $\left(1 \times 10^{6}\right.$ cells $\left./ \mathrm{mL}\right)$ were incubated for an additional $24 \mathrm{~h}$ with or without CSP-4 (25, 50, 100, and $200 \mu \mathrm{g} / \mathrm{mL}$ ). The cells were then collected and the protein was extracted using PRO-PREPTM protein extraction solution (iNtRON Biotechnology, Gyeonggi-do, Korea).

\section{Measurement of TNF- $\alpha$ and IL-1 $\beta$}

RAW 264.7 cells $\left(1 \times 10^{6}\right.$ cells $\left./ \mathrm{mL}\right)$ were seeded into a 12-well plate and incubated for $24 \mathrm{~h}$ as described above. Untreated cells (negative control) and cells exposed to $S$. aureus CCARM $0027\left(1 \times 10^{6} \mathrm{cfu} / \mathrm{mL}\right)$ were incubated for $12 \mathrm{~h}$ in the absence or presence of CSP-4 $(25,50,100$, and $200 \mu \mathrm{g} / \mathrm{mL})$ in DMEM supplemented with $10 \%$ bovine serum. The levels of pro-inflammatory cytokines in the supernatants were determined after 12 $h$ using mouse anti-TNF- $\alpha$ and anti-IL-1 $\beta$ antibodies based on absorbance at $450 \mathrm{~nm}$ using a microplate reader (VERSA Max microplate reader, Molecular Devices). Cytokine concentrations were also determined using TNF- $\alpha$ and IL-1 $\beta$ enzyme-linked immunosorbent assay kits (Koma Biotech, Seoul, Korea) [44].

\section{Immunocytochemistry}

RAW 264.7 cells $\left(1 \times 10^{6}\right.$ cells $\left./ \mathrm{mL}\right)$ were cultured for $12 \mathrm{~h}$ as described above and incubated for $6 \mathrm{~h}$ in the presence of $S$. aureus LTA $(1 \mu \mathrm{g} / \mathrm{mL})$ with or without CSP-4 $(100 \mu \mathrm{g} / \mathrm{mL})$. The cells were then washed in PBS, fixed in 4\% paraformaldehyde (15 $\mathrm{min})$, permeabilized using $0.5 \%$ Triton-X 100 diluted in PBS, washed again 3 times by gently shaking in PBS for 5 min each, blocked in a blocking buffer ( $5 \%$ bovine serum albumin in PBS), and then added to an 8 -well plate $(200 \mu \mathrm{L} /$ well $)$, in which they were incubated for $1 \mathrm{~h}$ with gentle shaking. Primary antibodies (TNF- $\alpha$, AbFrontier, Seoul, Korea, AB1793; and IL-1 $\beta$ AbFrontier, AB1413; 1:50 dilution) were then added to the cells for $24 \mathrm{~h}$ at $4^{\circ} \mathrm{C}$, after which the cells were washed 3 times in PBS ( $5 \mathrm{~min} /$ wash). A secondary antibody was applied (goat anti-mouse IgG-HRP, LF-SA 5001-conjugated; $1: 200$ dilution) for $1 \mathrm{~h}$ at $37^{\circ} \mathrm{C}$, and nuclei were stained using DAPI $(0.25 \mu \mathrm{g} / \mathrm{mL})$. The staining was visualized under a confocal laser-scanning microscope (LSM510; Carl Zeiss; Gottingen, Germany) [45].

\section{Immunohistochemistry}

Male hairless mouse (aged 6 weeks, 5 mouse/group, total 7 groups) were injected intraepidermal with $S$. aureus CCARM $0027\left(1 \times 10^{8} \mathrm{cfu} / \mathrm{ml}\right)$. The CSP-4 peptide (200, $100,50,25 \mu \mathrm{g} / \mathrm{ml}$ ) was injected intraeptidermal into mice at $1 \mathrm{~h}$ after the S. aureus CCARM 0027 injection, samples of inflamed skin was collected after 7 days and $4-\mu \mathrm{m}$-thick sections were prepared as described in the preceding section. Each sample was then incubated for $30 \mathrm{~min}$ at $24^{\circ} \mathrm{C}$ with $5 \%$ bovine serum albumin, mouse anti-Toll-like receptor-2 (TLR-2) (AbFrontier, AB24192), mouse monoclonal anti-TNF- $\alpha$ (AbFrontier, AB1793), and mouse polyclonal anti-IL-1 $\beta$ (AbFrontier, AB1413). The samples were then washed with Tris-buffered saline containing Tween 20 buffer and incubated with HRP LFSA5001-conjugated goat anti-mouse $\mathrm{IgG}$, and stained with hematoxylin and eosin. The stained sections were examined under a fluorescence microscope [46].

\section{Topical assay}

Topical delivery of rhodamine-labeled CSP-4 was evaluated on hairless mouse skin. Male hairless mice (6 weeks old) bred by Hoshino Laboratory Animals, Inc. (Bandou-shi, Japan) were purchased from Japan SLC, Inc. (Hamamatsu, Japan). After anesthetizing 5 mice per group (3 groups) with isoflurane, rhodamine-labeled CSP-4 (200 $\mu \mathrm{g} / \mathrm{mL}$ ) was spread on the hairless mouse skin. The skin was then examined for reactions every $5 \mathrm{~min}$ for $30 \mathrm{~min}$. Skin tissue was collected and washed once in PBS, fixed in $4 \%$ paraformaldehyde for $12 \mathrm{~h}$, dehydrated in $50 \%$ and $100 \%$ ethanol ( $2 \mathrm{~h}$ each), and washed 3 times in xylene substitute ( $1 \mathrm{~h} /$ wash). Paraffin-embedded samples were cut into $4 \mu \mathrm{m}$-thick sections (Microtome; Thermo Scientific, Waltham, MA, USA) and examined under a fluorescence microscope (IX71; Olympus; Tokyo, Japan) [38].

\section{Western blot analysis}

Western blot analysis was performed as using changes in protein expression. Briefly, proteins extracted from the hairless mouse skin were separated for $3 \mathrm{~h}$ using $15 \%$ SDS-polyacrylamide gel electrophoresis and transferred to polyvinylidene fluoride membranes (Bio-Rad, Hercules, CA, USA) for $1 \mathrm{~h}$ at $90 \mathrm{~V}$. The membranes were then incubated overnight at $4^{\circ} \mathrm{C}$ in $5 \%$ skim milk containing anti-GAPDH (LF-PA0018; Santa Cruz Biotechnology, Santa Cruz, CA, USA), mouse anti-TLR2 (AbFrontier, AB24192), mouse anti-NF-KB, (Santa Cruz Biotechnology, SC-71675), mouse anti-TNF- $\alpha$ (AbFrontier, AB1793), mouse antiIL-1 $\beta$ (AbFrontier, AB1413), and mouse anti-cathelicidin (AbFrontier, AB93357). The membranes were then washed in Tris-buffered saline containing Tween 20 and incubated 
with the horseradish peroxidase (HRP)-conjugated secondary antibodies LF-SA5002 goat anti-rabbit IgG and LF-SA5001 goat anti-mouse IgG. The blots were developed using a Western Blot Detection kit (AbFrontier, LF-QC0103) [45].

\section{Aggregation assay}

Light scattering assays were performed with clavaspirin and its analogue peptides using a Perkin-Elmer LS55 fluorometer. Peptides were dissolved in $10 \mathrm{mM}$ sodium phosphate buffer ( $\mathrm{pH} 5.5$ or $\mathrm{pH} 7.4$ ) and incubated for $12 \mathrm{~h}$ at $37^{\circ} \mathrm{C}$. Light scattering was excited at $400 \mathrm{~nm}$ and the emission was scanned at $400 \mathrm{~nm}$ [35].

\section{CD analysis}

Circular dichroism (CD) spectra were recorded at $25^{\circ} \mathrm{C}$ on a Jasco 810 spectropolarimeter (Jasco, Oklahoma City, OK, USA) equipped with a temperature control unit. A $0.1-\mathrm{cm}$ path length quartz cell was used with $50 \mu \mathrm{M}$ peptide solutions under various conditions, including $10 \mathrm{mM}$ sodium phosphate and $30 \mathrm{mM} \mathrm{SDS}(\mathrm{w} / \mathrm{v})$ at $\mathrm{pH}$ 5.5 and $\mathrm{pH}$ 7.4. At minimum, 5 scans were acquired and averaged to reduce the signal-to-noise ratio from 250 to

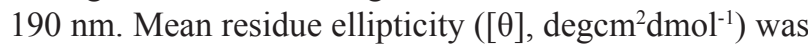
calculated using eq. 2 :

$[\theta]=\theta \mathrm{obs} / 10 \mathrm{cc}$ (eq. 2)

where $\theta$ obs is the measured signal (ellipticity) in millidegrees, $\mathrm{l}$ is the optical path-length of the cell in $\mathrm{cm}$, and $\mathrm{c}$ is the concentration of peptide in $\mathrm{M}$ and is calculated as the mean residue molar concentration (number of constructed residues of peptide $\times$ molar concentration of peptide (M)) [40].

\section{SYTOX-green uptake analysis}

S. aureus CCARM 259237 cells were grown to the mid-log phase and suspended in $10 \mathrm{mM}$ sodium phosphate buffer supplemented with $10 \%$ culture medium at $\mathrm{pH} 7.4$ and $37^{\circ} \mathrm{C}$, and then washed and suspended $\left(2 \times 10^{7} \mathrm{cfu} /\right.$ $\mathrm{mL})$ in $10 \mathrm{mM}$ sodium phosphate buffer $(\mathrm{pH} \mathrm{7.4)}$ and incubated with $1 \mu \mathrm{M}$ SYTOX-Green for $20 \mathrm{~min}$ in the dark. After the addition of peptides at the appropriate concentrations (1/2 MIC, MIC, $2 \times \mathrm{MIC}$, and/or $4 \times$ $\mathrm{MIC})$, time-dependent increases in fluorescence, which is caused by the binding of the cationic dye to intracellular nucleic acids, was monitored using a Perkin-Elmer LS55 fluorometer (excitation wavelength, $485 \mathrm{~nm}$; emission wavelength, $520 \mathrm{~nm})$ [40].

\section{Membrane depolarization of intact bacterial cells}

The membrane depolarizing activities of the peptides were evaluated in E. coli cells using the membrane potentialsensitive fluorescent dye DiSC3-5 (3,3'-dipropylthiadicarbo cyanine iodide). Two batches of bacterial cells (experiment and control) were grown to mid-log phase at $37^{\circ} \mathrm{C}$, harvested, and washed three times with buffer A (20 mM glucose, 5 $\mathrm{mM}$ HEPES [pH 7.2]). The cells were then resuspended to an $A 600$ of 0.05 in buffer A containing $0.1 \mathrm{M} \mathrm{KCl}$, after which DiSC3-5 was added to a final concentration of $0.1 \mathrm{M}$ and the mixture was incubated for $60 \mathrm{~min}$ until the fluorescence level stabilized. The peptides were then added to bacterial suspensions, and the changes in fluorescence were continuously recorded (excitation at $622 \mathrm{~nm}$ and emission at $670 \mathrm{~nm}$ ) for $30 \mathrm{~min}[36]$.

\section{Membrane disruption analysis}

Large unilamellar vesicles (LUVs) were prepared using the freeze-thaw method. The desired mixture of phospholipids (PE/PG, 7:3) was dissolved in chloroform, dried in a glass tube under nitrogen, and then lyophilized overnight to remove solvent residues. The dry phospholipid films were resuspended in 1-2 mL of $5 \mathrm{mM}$ HEPES buffer ( $\mathrm{pH} 5.5$ or $\mathrm{pH} 7.4$ ) containing $100 \mu \mathrm{g} / \mathrm{mL}$ FD-FITC-dextran, and the resulting mixtures were vortexed. LUVs were prepared using eight freezethaw cycles in liquid nitrogen and incubated in a water bath at $50^{\circ} \mathrm{C}$. Once vesicles were prepared, suspensions of LUVs were extruded 10 times through polycarbonate membranes with 0.2- $\mu \mathrm{m}$ diameter pores using an Avanti Mini-Extruder (Avanti polar Lipids Inc., Alabaster, AL, USA), after which vesicles with entrapped FD-FITCdextran were separated from free FD-FITC-dextran by gel filtration chromatography with a Sephadex G-50 column. The vesicle concentration was determined using standard phosphate assays. LUVs were entrapped of FDFITC dextran in suspension giving $10 \mu \mathrm{M}$ phospholipid (PE/PG, 7:3). And then, the liposome was incubated with MIC of CSP-4 in HEPES buffer ( $\mathrm{pH} 5.5$ or $\mathrm{pH}$ 7.4). The fluorescence of the released FD-FITC-dextran was assessed using a spectrofluorometer (PerkinElmer LS55) at an excitation wavelength of $490 \mathrm{~nm}$ and emission wavelength of $520 \mathrm{~nm}$. Complete $(100 \%)$ release was achieved by addition of Triton X-100 to a final concentration of $0.1 \%(\mathrm{w} / \mathrm{v})$ [47].

\section{Time-kill kinetics}

E. coli were grown overnight in LB broth ( $\mathrm{pH} 5.5$ or $\mathrm{pH}$ 7.4) and diluted to an $\mathrm{OD}_{600}$ of 0.05. CSP-4 was then added so that the final concentration was either the MIC or $1 / 2$ MIC. E. coli cells were then sampled at 1-min intervals for the first $10 \mathrm{~min}$ and at 10 -min intervals thereafter for 2 h. The cultures were then diluted 50-fold in PBS buffer and plated on LB agar. Colonies were counted after $24 \mathrm{~h}$ [48].

\section{Confocal laser scanning microscopy analysis}

The cellular distributions of clavaspirin and its analogues were determined in E. coli cells using confocal laser scanning microscopy and rhodamine- 
labeled peptides. The cells were incubated for $24 \mathrm{~h}$ at $37^{\circ} \mathrm{C}$ in LB media ( $\mathrm{pH} 5.5$ or $\mathrm{pH} 7.4$ ). Rhodaminelabeled peptides were added to $100 \mu \mathrm{L}$ of cells at the respective MICs. After incubation for $20 \mathrm{~min}$, the cells were pelleted by centrifugation at $4000 \times g$ for $5 \mathrm{~min}$ and washed three times with ice-cold $10 \mathrm{mM}$ sodium phosphate buffer ( $\mathrm{pH} 5.5$ or $\mathrm{pH}$ 7.4). Rhodamine-labeled peptides were imaged using a LSM 510 Laser Scanning microscope (Carl Zeiss). The cells were illuminated using a 405-nm line diode laser and 543-nm helium neon laser. The light was directed through a UV 148/154/633 beam splitter, and images were recorded digitally in a $512 \times 512$ pixel format [40].

\section{Preparation and visualization of GUVs}

Giant unilamellar vesicles (GUVs) were prepared using the electroformation method. Briefly, phospholipid mixtures were prepared in chloroform-methanol (9:1). The mixtures used were PE/PG/PE-rhodamine (69/30/1) and PE/PG (7:3). One hundred microliters of lipid mixture were then deposited onto indium tin oxide (ITO)-coated glass slides $(25 \times 35 \times 1.1 \mathrm{~mm}$, Sigma-Aldrich, St. Louis, MO, USA), which were then spin-coated at 600 rpm for $5 \mathrm{~min}$. After removing residual organic solvents by evacuation in a vacuum for at least $2 \mathrm{~h}$, two ITO glass slides (one with a lipid film) were arranged with a poly(dimethylsiloxane) spacer to form an electroformation chamber $(25 \times 25 \times 1 \mathrm{~mm})$. The chamber was filled with $5 \mathrm{mM}$ HEPES buffer ( $\mathrm{pH} 5.5$ or $\mathrm{pH}$ 7.4) containing 0.1 $\mathrm{M}$ sucrose through a hole in the spacer. A $1.7 \mathrm{~V}$ (peak to peak), $10 \mathrm{~Hz}$ AC field was then immediately applied to the ITO slides using a function generator (Agilent 33220A, Agilent Technologies, Santa Clara, CA, USA). After 1.5 $\mathrm{h}$, the electric field was changed to $4 \mathrm{~V}, 4 \mathrm{~Hz}$ for $10 \mathrm{~min}$ to detach the liposomes formed on the slides. The liposome solution was gently removed from the electroformation chamber, and aliquots were diluted in $5 \mathrm{mM}$ HEPES buffer containing $0.1 \mathrm{M}$ glucose. Aliquots of the resultant GUV suspension were deposited on microscope slides and allowed to settle for $1 \mathrm{~min}$. The settling occurred because of the density difference between the sugar solutions inside and outside the liposomes. The liposomes were then examined under an inverted fluorescence phase contrast microscope (IX71, Olympus), and images were recorded using a digital CCD camera (DP71, Olympus) and video recorder. Images were analyzed using software provided by the manufacturer [49].

\section{SEM analysis}

For scanning electron microscopy (SEM), S. aureus cells were cultured in LB medium ( $\mathrm{pH} 5.5$ or $\mathrm{pH} 7.4$ ), washed 3 times with $10 \mathrm{mM}$ sodium phosphate buffer, and stirred at $4000 \mathrm{rpm}$. CSP-4 was added to the cells and incubated at $25^{\circ} \mathrm{C}$. After incubation, the cells were fixed in $4 \%$ glutaraldehyde for $20 \mathrm{~min}$ and dehydrated in 50\% and then $100 \%$ ethanol (10 min each step) at $37^{\circ} \mathrm{C}$. In addition, 7 days after inducing inflammation in hairless mouse skin tissue by infection with drug-resistant $S$. aureus CCARM 0027 strain or E. coli bacteria, samples of skin tissue were isolated, washed in PBS, fixed in $4 \%$ paraformaldehyde overnight at $4^{\circ} \mathrm{C}$, and dehydrated in $50 \%$ and then $100 \%$ ethanol ( $2 \mathrm{~h}$ each step) at $37^{\circ} \mathrm{C}$. Samples were then gold-coated and visualized by SEM (JSM-7100F; JEOL, Tokyo, Japan) [50].

\section{TEM analysis}

For transmission electron microscopy (TEM), $E$. coli cells were cultured in LB medium ( $\mathrm{pH} 5.5$ or 7.4), and then washed 3 times with $10 \mathrm{mM}$ sodium phosphate buffer ( $\mathrm{pH} 5.5$ or $\mathrm{pH} 7.4$ ) at $4000 \mathrm{rpm}$. CSP-4 was added to the cells at $25^{\circ} \mathrm{C}$. After incubation, the cells were applied to glow-discharged carbon-coated copper grids for $1 \mathrm{~min}$. The grids were then rinsed in saline buffer and stained with $2 \%(\mathrm{w} / \mathrm{v})$ uranyl acetate, after which electron micrographs were recorded using a FEI Technei 12 microscope (FEI Company, Hillsboro, OR, USA) with an acceleration voltage of $120 \mathrm{kV}$ [40].

\section{Statistics}

The data were analyzed using SPSS version 20.0 (Chicago, IL, USA). Values are presented as means \pm SD. One-way ANOVA was used to compare resistance development, LPS or LTA binding affinity, TNF- $\alpha$, IL- $1 \beta$, peptide aggregation, SYTOX-Green uptake, and timekill kinetics levels between the absence and/or presence of CSP-4. A $P$-value less than 0.05 were considered statistically significant.

\section{Study approval}

This study was approved by the Institutional Ethics Committee of Chosun University, and all healthy donors provided printed informed consent before the start of experimentation. All procedures complied with the ethical standards of this committee as well as the checklist for ethical concern of cytotoxicity studies. Human red blood cells (RBCs) were obtained from newly collected blood samples from 5 healthy donors at the Chosun University Hospital in Kwangju, Republic of Korea. Furthermore, we obtained an ethics agreement from the Institutional Ethics Committee of Chosun University. The authors of this article were unsighted to all individual information from the donors, who remained nameless throughout the experimental process. After collection, blood samples were directly stored at $4^{\circ} \mathrm{C}$ until required. The mouse studies were performed in accordance with the National Institutes of Health guidelines for the ethical treatment of animals. All animal processes also conformed to the Experimental Animal Center of Chosun University guidelines. All work was covered by the following 
license from the Experimental Animal Center of Chosun University: CIACUC 2015-A0026, "Antibacterial activity of AMP (CSP-4)."

\section{Author contributions}

Y.P. planned the research project, J.K.L. performed the experiments, analyses, and prepared the figures, and Y.P., T.L., and J.K.L. wrote the manuscript. All authors contributed to the interpretation and reviewed the manuscript.

\section{CONFLICTS OF INTEREST}

The authors declare that there is no conflicts of interests regarding the publication of this paper.

\section{FUNDING}

This work was supported by a National Research Foundation of Korea (NRF) grant funded by the Korean Government (No. 2016R1A2A1A05005440), Global Research Laboratory (GRL) Grant (No. NRF2014K1A1A2064460) and Institute for Information \& communications Technology Promotion (IITP) grant funded by the Korea government (MSIT) (No. 2017-001714, Development of Antimicrobial Peptide using Deep Learning).

\section{REFERENCES}

1. Ling LL, Schneider T, Peoples AJ, Spoering AL, Engels I, Conlon BP, Mueller A, Schäberle TF, Hughes DE, Epstein S, Jones M, Lazarides L, Steadman VA, et al. A new antibiotic kills pathogens without detectable resistance. Nature. 2015; 517:455-459.

2. Gould IM, David MZ, Esposito S, Garau J, Lina G, Mazzei T, Peters G. New insights into meticillin-resistant Staphylococcus aureus (MRSA) pathogenesis, treatment and resistance. Int J Antimicrob Agents. 2012; 39:96-104.

3. Brown D. Antibiotic resistance breakers: can repurposed drugs fill the antibiotic discovery void? Nat Rev Drug Discov. 2015; 14:821-832.

4. Krishna S, Miller LS. Innate and adaptive immune responses against Staphylococcus aureus skin infections. Semin Immunopathol. 2012; 34:261-280.

5. Yuan K, Huang C, Fox J, Gaid M, Weaver A, Li G, Singh BB, Gao H, Wu M. Elevated inflammatory response in caveolin-1-deficient mice with Pseudomonas aeruginosa infection is mediated by STAT3 protein and nuclear factor kappaB (NF-kappaB). J Biol Chem. 2011; 286:21814-21825.
6. Browne SK, Holland SM. Anticytokine autoantibodies in infectious diseases: pathogenesis and mechanisms. Lancet Infect Dis. 2010; 10:875-885.

7. Nomiyama H, Hieshima $\mathrm{K}$, Osada N, Kato-Unoki $\mathrm{Y}$, Otsuka-Ono K, Takegawa S, Izawa T, Yoshizawa A, Kikuchi Y, Tanase S, Miura R, Kusuda J, Nakao M, et al. Extensive expansion and diversification of the chemokine gene family in zebrafish: identification of a novel chemokine subfamily CX. BMC Genomics. 2008; 9:222.

8. Ma L, Wang Y, Wang M, Tian Y, Kang W, Liu H, Wang H, Dou J, Zhou C. Effective antimicrobial activity of Cbf14 , derived from a cathelin-like domain, against penicillinresistant bacteria. Biomaterials. 2016; 87:32-45.

9. Melo MN, Ferre R, Castanho MA. Antimicrobial peptides: linking partition, activity and high membrane-bound concentrations. Nat Rev Microbiol. 2009; 7:245-250.

10. Lee IH, Zhao C, Nguyen T, Menzel L, Waring AJ, Sherman MA, Lehrer RI. Clavaspirin, an antibacterial and haemolytic peptide from Styela clava. J Pept Res. 2001; 58:445-456.

11. Hayouka Z, Thomas NC, Mortenson DE, Satyshur KA, Weisblum B, Forest KT, Gellman SH. Quasiracemate Crystal Structures of Magainin 2 Derivatives Support the Functional Significance of the Phenylalanine Zipper Motif. J Am Chem Soc. 2015; 137:11884-11887.

12. Asthana N, Yadav SP, Ghosh JK. Dissection of antibacterial and toxic activity of melittin: a leucine zipper motif plays a crucial role in determining its hemolytic activity but not antibacterial activity. J Biol Chem. 2004; 279:55042-55050.

13. Dhe-Paganon S, Werner ED, Nishi M, Hansen L, Chi YI, Shoelson SE. A phenylalanine zipper mediates APS dimerization. Nat Struct Mol Biol. 2004; 11:968-974.

14. Ibrahim HR, Imazato K, Ono H. Human lysozyme possesses novel antimicrobial peptides within its $\mathrm{N}$-terminal domain that target bacterial respiration. J Agric Food Chem. 2011; 59:10336-10345.

15. Ahmad A, Azmi S, Srivastava S, Kumar A, Tripathi JK, Mishra NN, Shukla PK, Ghosh JK. Design and characterization of short antimicrobial peptides using leucine zipper templates with selectivity towards microorganisms. Amino Acids. 2014; 46:2531-2543.

16. Ghosal A, Nielsen PE. Potent antibacterial antisense peptidepeptide nucleic acid conjugates against Pseudomonas aeruginosa. Nucleic Acid Ther. 2012; 22:323-334.

17. Gaya M, Castello A, Montaner B, Rogers N, Reis e Sousa C, Bruckbauer A, Batista FD. Host response. Inflammation-induced disruption of SCS macrophages impairs B cell responses to secondary infection. Science. 2015; 347:667-672.

18. Lehar SM, Pillow T, Xu M, Staben L, Kajihara KK, Vandlen R, DePalatis L, Raab H, Hazenbos WL, Morisaki JH, Kim J, Park S, Darwish M, et al. Novel antibody-antibiotic conjugate eliminates intracellular S. aureus. Nature. 2015; 527:323-328. 
19. Wyatt MA, Wang W, Roux CM, Beasley FC, Heinrichs DE, Dunman PM, Magarvey NA. Staphylococcus aureus nonribosomal peptide secondary metabolites regulate virulence. Science. 2010; 329:294-296.

20. Cederlund A, Gudmundsson GH, Agerberth B. Antimicrobial peptides important in innate immunity. FEBS J. 2011; 278:3942-3951.

21. King AM, Reid-Yu SA, Wang W, King DT, De Pascale G, Strynadka NC, Walsh TR, Coombes BK, Wright GD. Aspergillomarasmine A overcomes metallo- $\beta$-lactamase antibiotic resistance. Nature. 2014; 510:503-506.

22. Conlon BP, Nakayasu ES, Fleck LE, LaFleur MD, Isabella VM, Coleman K, Leonard SN, Smith RD, Adkins JN, Lewis K. Activated ClpP kills persisters and eradicates a chronic biofilm infection. Nature. 2013; 503:365-370.

23. Yadav SP, Ahmad A, Ghosh JK. Addition of a small hydrophobic segment from the head region to an amphipathic leucine zipper like motif of E. coli toxin hemolysin E enhances the peptide-induced permeability of zwitterionic lipid vesicles. Biochim Biophys Acta. 2007; 1768:1574-1582.

24. Yadav SP, Ahmad A, Pandey BK, Verma R, Ghosh JK. Inhibition of lytic activity of Escherichia coli toxin hemolysin E against human red blood cells by a leucine zipper peptide and understanding the underlying mechanism. Biochemistry. 2008; 47:2134-2142.

25. Ahmad A, Asthana N, Azmi S, Srivastava RM, Pandey BK, Yadav V, Ghosh JK. Structure-function study of cathelicidin-derived bovine antimicrobial peptide BMAP28: design of its cell-selective analogs by amino acid substitutions in the heptad repeat sequences. Biochim Biophys Acta. 2009; 1788:2411-2420.

26. Pandey BK, Ahmad A, Asthana N, Azmi S, Srivastava RM, Srivastava S, Verma R, Vishwakarma AL, Ghosh JK. Cellselective lysis by novel analogues of melittin against human red blood cells and Escherichia coli. Biochemistry. 2010; 49:7920-7929.

27. Jonigk D, Al-Omari M, Maegel L, Müller M, Izykowski N, Hong J, Hong K, Kim SH, Dorsch M, Mahadeva R, Laenger F, Kreipe H, Braun A, et al. Anti-inflammatory and immunomodulatory properties of $\alpha 1$-antitrypsin without inhibition of elastase. Proc Natl Acad Sci USA. 2013; 110:15007-15012.

28. Kawai T, Akira S. Toll-like receptors and their crosstalk with other innate receptors in infection and immunity. Immunity. 2011; 34:637-650.

29. Lande R, Botti E, Jandus C, Dojcinovic D, Fanelli G, Conrad C, Chamilos G, Feldmeyer L, Marinari B, Chon S, Vence L, Riccieri V, Guillaume P, et al. The antimicrobial peptide LL37 is a T-cell autoantigen in psoriasis. Nat Commun. 2014; 5:5621.

30. Jarczak J, Kościuczuk EM, Lisowski P, Strzałkowska N, Jóźwik A, Horbańczuk J, Krzyżewski J, Zwierzchowski L,
Bagnicka E. Defensins: natural component of human innate immunity. Hum Immunol. 2013; 74:1069-1079.

31. Köten B, Becker K, Podschun R, von Eiff C, Meyer-Hoffert U, Harder J, Gläser R. Susceptibility of Staphylococcus aureus bacteremia strains to different skin-derived antimicrobial proteins. Arch Dermatol Res. 2012; 304:633-637.

32. Simanski M, Dressel S, Gläser R, Harder J. RNase 7 protects healthy skin from Staphylococcus aureus colonization. J Invest Dermatol. 2010; 130:2836-2838.

33. Schittek B. The multiple facets of dermcidin in cell survival and host defense. J Innate Immun. 2012; 4:349-360.

34. Rothbard JB, Garlington S, Lin Q, Kirschberg T, Kreider E, McGrane PL, Wender PA, Khavari PA. Conjugation of arginine oligomers to cyclosporin A facilitates topical delivery and inhibition of inflammation. Nat Med. 2000; 6:1253-1257.

35. Yoneyama F, Imura Y, Ohno K, Zendo T, Nakayama J, Matsuzaki K, Sonomoto K. Peptide-lipid huge toroidal pore, a new antimicrobial mechanism mediated by a lactococcal bacteriocin, lacticin Q. Antimicrob Agents Chemother. 2009; 53:3211-3217.

36. Nguyen LT, Haney EF, Vogel HJ. The expanding scope of antimicrobial peptide structures and their modes of action. Trends Biotechnol. 2011; 29:464-472.

37. Kacprzyk L, Rydengård V, Mörgelin M, Davoudi M, Pasupuleti M, Malmsten M, Schmidtchen A. Antimicrobial activity of histidine-rich peptides is dependent on acidic conditions. Biochim Biophys Acta. 2007; 1768:2667-2680.

38. Gautam A, Nanda JS, Samuel JS, Kumari M, Priyanka P, Bedi G, Nath SK, Mittal G, Khatri N, Raghava GP. Topical Delivery of Protein and Peptide Using Novel Cell Penetrating Peptide IMT-P8. Sci Rep. 2016; 6:26278.

39. Resende JM, Verly RM, Aisenbrey C, Cesar A, Bertani P, Piló-Veloso D, Bechinger B. Membrane interactions of phylloseptin-1, -2 , and -3 peptides by oriented solid-state NMR spectroscopy. Biophys J. 2014; 107:901-911.

40. Lee JK, Park SC, Hahm KS, Park Y. A helix-PXXP-helix peptide with antibacterial activity without cytotoxicity against MDRPA-infected mice. Biomaterials. 2014; 35:1025-1039.

41. Nan YH, Park KH, Jeon YJ, Park Y, Park IS, Hahm KS, Shin SY. Antimicrobial and anti-inflammatory activities of a Leu/Lys-rich antimicrobial peptide with Phe-peptoid residues. Protein Pept Lett. 2007; 14:1003-1007.

42. Dartois V, Sanchez-Quesada J, Cabezas E, Chi E, Dubbelde C, Dunn C, Granja J, Gritzen C, Weinberger D, Ghadiri MR, Parr TR Jr. Systemic antibacterial activity of novel synthetic cyclic peptides. Antimicrob Agents Chemother. 2005; 49:3302-3310.

43. Bannatyne RM, Jackowski J, Grant RB. Antibacterial activity of niridazole against Salmonellae. Antimicrob Agents Chemother. 1986; 29:923-924. 
44. Muangnoi C, Chingsuwanrote P, Praengamthanachoti P, Svasti S, Tuntipopipat S. Moringa oleifera pod inhibits inflammatory mediator production by lipopolysaccharidestimulated RAW 264.7 murine macrophage cell lines. Inflammation. 2012; 35:445-455.

45. Nasu T, Kinomura M, Tanabe K, Yamasaki H, Htay SL, Saito D, Hinamoto N, Watatani H, Ujike H, Suzuki Y, Sugaya T, Sugiyama H, Sakai Y, et al. Sustainedrelease prostacyclin analog ONO-1301 ameliorates tubulointerstitial alterations in a mouse obstructive nephropathy model. Am J Physiol Renal Physiol. 2012; 302:F1616-1629.

46. Tewari-Singh N, Rana S, Gu M, Pal A, Orlicky DJ, White $\mathrm{CW}$, Agarwal R. Inflammatory biomarkers of sulfur mustard analog 2-chloroethyl ethyl sulfide-induced skin injury in SKH-1 hairless mice. Toxicol Sci. 2009; 108:194-206.

47. Domingues MM, Castanho MA, Santos NC. rBPI(21) promotes lipopolysaccharide aggregation and exerts its antimicrobial effects by (hemi)fusion of PG-containing membranes. PLoS One. 2009; 4:e8385.

48. Jeong N, Kim JY, Park SC, Lee JK, Gopal R, Yoo S, Son BK, Hahm JS, Park Y, Hahm KS. Antibiotic and synergistic effect of Leu-Lys rich peptide against antibiotic resistant microorganisms isolated from patients with cholelithiasis. Biochem Biophys Res Commun. 2010; 399:581-586.

49. Estes DJ, Mayer M. Electroformation of giant liposomes from spin-coated films of lipids. Colloids Surf B Biointerfaces. 2005; 42:115-123.

50. Park Y, Park SN, Park SC, Shin SO, Kim JY, Kang SJ, Kim MH, Jeong CY, Hahm KS. Synergism of Leu-Lys rich antimicrobial peptides and chloramphenicol against bacterial cells. Biochim Biophys Acta. 2006; 1764:24-32. 